Ankara Üniversitesi

SBF Dergisi,

Cilt 72, No. 1, 2017, s. $35-76$

\title{
TÜRKIYE'DE ERKEK HEMŞIRE OLMAK: AVANTAJLAR ve DEZAVANTAJLAR
}

\author{
Yrd. Doç. Dr. Temmuz Gönç \\ Anadolu Üniversitesi \\ Edebiyat Fakültesi
}

\section{Öz}

Bu çalışmanın amacı, Türkiye'de hemşire olma deneyiminin öne çıkan yönlerini hemşirelerin gözünden betimlemek, hemşireliğin erkekler açısından avantaj ve dezavantajlarını literatürdeki benzer çalışmalarla kıyaslayarak irdelemek ve sosyolojik olarak değerlendirmektir. Çalışma, 2015 yılında gerçekleştirilen, fenomenolojik desene sahip nitel bir alan araştırmasına dayanmaktadır. Örneklem, yarısı erkek yarısı kadın olan 42 hemşireden oluşmaktadır, veriler derinlemesine mülakatlarla toplanmış ve betimsel ve sistematik olarak analiz edilmiş̧ir. Bulgular, erkek hemşirelerin avantajlarının da dezavantajlarının da hegemonik erkeklik normları çerçevesinde deneyimlendiğini göstermektedir. Erkek hemşireler toplumsal cinsiyet kalıp yargılarını meslek içine taşıyarak ve sembolik şiddet uygulayarak meslek içinde avantajlı pozisyonlardan kadınları dışlamaktadırlar. Kadınların meslekte ilerlemesini sınırlandıran cam tavanı sağlamlaştıran bu süreç, erkek hemşirelerin en önemli avantajıdır. Erkek hemşirelerin başlıca dezavantajları ise hegemonik erkeklik normları ve meslek normları arasında sıkışmaları, kadın hastalara dokunmayı gerektiren durumlarda muhtemel cinsel taciz suçlamalarına ilişkin kaygı duymaları ve kadın yoğun bir meslekte çalıştıkları için cinsel kimliklerinin sorgulanmasıdır.

Anahtar Sözcükler: Meslekler Sosyolojisi, Toplumsal Cinsiyet Sosyolojisi, Kadın Çalışmaları, Erkek Hemşireler, Hegemonik Erkeklik

\section{Being a Male Nurse in Turkey: Advantages and Disadvantages}

\begin{abstract}
The aim of this study is to describe the nurses' opinions on male nurses' occupational experiences, to compare the advantages and disadvantages of being a male nurse in Turkey with related literature and to make a sociological evaluation. The study draws on the data of a qualitative field research conducted in 2015. The sample consists of 42 nurses, of whom half are male and half are female. The data are collected by indepth interviews and analyzed descriptively and systematically. The findings show that both the advantages and the disadvantages of male nurses are experienced around hegemonic masculinity. By transferring gender stereotypes into occupational area and by practicing symbolic violence, male nurses exclude female nurses from advantageous positions in the occupation. This process strengthens glass ceiling, which limits female nurses' career advancements, and seems to be the most important advantage of male nurses. The main disadvantages of male nurses are to be stuck between hegemonic masculinity norms and occupational norms; the concerns about female patients' potential charges of sexual harassment; and the implicit suspicions about their heterosexuality.
\end{abstract}

Keywords: Sociology of Occupations, Sociology of Gender, Gender Studies, Male Nurses, Hegemonic Masculinity

* Makale geliş tarihi: 15.12 .2015

Makale kabul tarihi: 25.05.2016 


\section{Türkiye'de Erkek Hemşire Olmak: Avantajlar ve Dezavantajlar}

\section{Giriş}

$\mathrm{Bu}$ çalışmanın amacı, kadın yoğun bir mesleğe girmiş olan erkek hemşirelerin mesleki deneyimlerini betimlemek ve çalışma yaşamındaki avantaj ve dezavantajlarını sosyolojik olarak değerlendirmektir. Erkeklerin hemşirelik mesleğine girişi, işgücü piyasalarının cinsiyete göre dikey olarak ayrışması çerçevesinde kadın meslektaşlarına göre avantajlı konumlarda çalışmalarına neden olabileceği gibi (Hader, 2005; Muench vd., 2015), bir kadın işi yaptıkları için yadırganmalarına ve etiketlenmelerine de yol açabilmektedir (Harding, 2007; Brown, 2009). Aktif olarak çalışan kadın ve erkek hemşirelerle yürütülmüş nitel bir alan araştırmasının verilerine dayanan bu çalışma, erkek hemşirelerin meslekteki avantaj ve dezavantajlarını birbirleriyle ilişkili olarak ele almayı amaçlamaktadır.

Hemşireliğin bir kadın mesleği olarak kabul edilmesi, dünya genelinde erkek hemşire sayısının oldukça sınırlı kalmasına neden olmuştur. Erkekler, 1970'lerden itibaren artan hemşire açı̆̆ nedeniyle hemşirelik mesleğine girmeye teşvik edilmişlerse de meslekte kadınların sayıca üstünlügü sürmektedir (Meadus ve Twomey, 2007). Bu nedenle erkek hemșirelerin mesleki deneyimlerini incelemeden önce, hemşireliğin kadın yoğun bir meslek olmasının, diğer bir deyişle hemşireliğin feminizasyonunun nedenleri üzerinde durmak yerinde olacaktır.

\section{Hemşirelik Mesleğinin Feminizasyonunun Nedenleri}

Ataerkil ideoloji ilk çağlardan itibaren kadını erkeğe göre ikincil ve daha az değerli gösteren varsayımlara dayanmış, hemşirelik mesleğinin yapısı ve statüsü büyük ölçüde bu varsayımlar etrafında şekillenmiştir. Pisagor M.Ö. 6 . yüzyılda düzenlediği karşıtlık tablosunda erkekliği açıklık ve etkinlikle ilişkilendirirken kadınlı̆̆ muğlaklık ve edilgenlikle ilişkilendirmiş, biçimlendirici olan erkek, biçimi kabul eden kadından üstün görülmüştür (Lloyd, 1996: 23-24). Batı düşünce tarihinde Aristo'dan Aquinas'a dek ilk dönem düşünceler kadını, özünde erkek olan insanlığa bir ek ya da yük olarak göstermiş, erkeklik ve kadınlık arasında kurulan çağrışımlar efendi köle ilişkisi metaforunu yinelemiştir (Lloyd, 1996: 26, 61). Tek tanrılı dinlerle birlikte güçlenen eril üstünlük paradigması M.Ö. 3. yüzyıldan itibaren kadınların 
doktorluk ve şifacılık yapmalarının yasaklanmasına neden olmuş ve Orta Çağ'da şifacı kadınları tahakküm altına almaya çalışan Engizisyonun, kadınların kötü ve şeytani oldukları yönündeki iddiasına temel oluşturmuştur. Avrupa genelinde Katolik Kilisesi'nin doktrinine bağlı olarak çalışan ve bilimsel kökeni olmayan dinsel tedaviler uygulayan erkek doktorların aksine, kadın şifacılar Kilisenin karşı olduğu ampirik yöntemi kullanmışlardır (Ehrenreich ve English, 1992: 25, 30). Hem bu nedenle hem de Kilisenin nüfus politikasıyla ilgili çıkarlarına aykırı olarak kürtaj yapmaya devam ettikleri için şifacı kadınlar Avrupa genelinde büyücü ve cadı olmakla suçlanmış ve 14 . yüzyıldan 17. yüzyıla dek süren cadı avlarında sistematik olarak öldürülmüşlerdir (Federici, 2012: 50-55; Ehrenreich ve English, 1992: 22-31).

He ne kadar modern tıbbın kurucularından biri sayılan Paracelsus, bildiği her şeyi büyücü kadınlardan öğrendiğini söylemişse de (Ehrenreich ve English, 1992: 31) kadınlar, doğuşundan itibaren modern bilimden de dışlanmıştır. Modern bilimin doğuşunda bilinebilir doğa "kadınsı bir şey gibi" sunulmuş ve bilimin görevi de "bu kadın üzerinde doğru türden bir erkek tahakkümü kurmak" olarak görülmüştür (Lloyd, 1996: 33). Akıl ve doğay1 "iffetli bir yoldan evlendirmek" gerektiğini ileri süren Francis Bacon, doğanın sırlarının ancak baskı altına alındığı zaman keşfedilebileceğini savunmuştur (Bacon, 1964'ten aktaran Llyod, 1996: 61). Bilim ve erkeklik arasında kurulan ilişkiye dikkat çeken Fox Keller (1995: 28)'a göre, bilimin kadınları dışlayan eril bir söylemle inşa edilmesi, düşünme şeklimizi etkilemektedir. Modern bilimin doğuşunda bilimsel alanın dışında bırakılan kadınlar tıp eğitiminden de sistematik olarak dışlanmış, formel eğitim alamadıkları için de yaptıkları işlemler yasa dışı olarak kabul edilmiş, hatta 1900'lerin başında kadınların ebelik yapması bile yasaklanmıştır (Ehrenreich ve English, 1992: 38, 56).

Tıp alanından dışlanan kadınlar, 19. yüzyılın ikinci yarısından itibaren Florence Nightingale tarafından kurulan hemşirelik mesleğine yönlendirilmişlerdir. Ancak mesleğin kuruluşu sürecinde Nightingale, hemşirenin doktora tabi konumu kabul eden, hemşirelik işini kadının ev içi emeğinin doğal uzantısı olarak gören, mesleği kadınlıkla, özellikle annelikle ilişkilendiren bir anlayışı benimsemiştir (Ehrenreich ve English, 1992). Nightingale'in cinsiyetçi ve sınıfsal bir şekilde kurduğu hemşirelik mesleğinin eğitim sürecinde öğrencilere sanat yorumu, makyaj, çay servisi gibi dersler verilmiş ve üst sınıfın ahlaki ve kültürel değerleri dayatılmıştır (Ehrenreich ve English, 1992: 61-63). Erkeklerin aksine kadınların doktor olma hakkına sahip olmadığını savunan Nightingale, hemşireliğe doktorluğa benzer mesleki sınavlar getirilmesine de karşı çıkmış, hatta savaş sırasındaki acil durumlarda bile hemşirelere, doktorlardan talimat almadan yaralı askerlere "parmaklarını bile dokundurmamaları gerektiğini" salık vermiştir (Ehrenreich ve English, 1992: 65). Böylece hemşirelik kuruluşundan itibaren özerklikten yoksun ve 
doktora bağımlı şekilde kurulmuştur. $\mathrm{Bu}$ yap1, modern toplumda sağlık işgücünün ve sağlıkla ilgili mesleklerin cinsiyetçi bir şekilde ayrışmasını kolaylaştırmıştır. Bu çerçevede akıl, bilim ve teknikle ilişkilendirilen erkekler tedavi görevini üstlenerek doktorluk mesleğinde yoğunlaşırken duygusallıkla ilişkilendirilen ve erkek otoritesine tabi olduğu varsayılan kadınlar da bakım işlerinde ve hemşirelik mesleğinde yoğunlaşmışlardır (Evans, 2004).

Nightingale'in mesleği annelikle ilişkilendirmesi, hemşirenin anne, doktorun baba, hastanın da çocuk olarak görüldüğü aile sembolizminin kurulmasında etkili olmuştur. Tıbbi işlerle bakım işlerini birbirinden ayırmak için kullanılan bu sembolizmde doktor babayla özdeşleştirilir; baba bilimsel bilgiye, yüksek statüye ve anneyle çocuğu kontrol edip yönetecek özerkliğe sahiptir. Hemşire ise bilimsel bilgiden daha az prestijli olan pratik bilgiye sahip olan ve görevi babanın, yani doktorun verdiği görevleri yerine getirmekten ibaret olan anne olarak görülür (Street, 1992: 49). Dolayısıyla hemşirelerin doktorlara göre ikincil konumu, özel alanda erkeklerin kadınlar üzerindeki tahakkümünün çalışma yaşamına yansımasını içerir. Bu yansıma, erkeklerin kadınlar üzerindeki tahakkümünü pekiştirir; çünkü özel alanda olduğu gibi kamusal alanda da kadınların ikincil konumda olması, kadınların düşük ücretle çalışması sayesinde pekişir. Böylece işgücü piyasasında yapılan işler ve bu işler için gerekli olan vasıflar cinsiyete göre ayrışır ve erkeklere oranla kadınların vasıfları ve yaptıkları işler daha değersiz kabul edilir (Cockburn, 1983: 171, 195). Bu çerçevede hemşireliğin düşük statülü ve düşük ücretli bir iş olması, yapılan işin bilimsel olması veya olmamasıyla değil, ağırlıkla kadınların yaptığı bir iş olmasıyla ilgilidir (Turner, 2011: 172-173; Philips ve Taylor, 1980: 80).

Yüksek eğitim ve vasıf gerektiren profesyonel mesleklerden dışlanan kadınlar (Walby, 1990) cinsiyete göre ayrışmış olan işgücü piyasasına girdiklerinde, zaten önceden belirlenmiş olan ve kadınlara uygun olduğu düşünülen iş ve mesleklerde yoğunlaşırlar (Ecevit, 1998: 277). Kadınlara uygun görülen ve sabır, pasiflik, dakiklik, incelik gibi nitelikler gerektiren bu "pembe yakalı" iş ve meslekler, aktiflik, fiziksel güç, teknik beceri gibi nitelikler gerektiren erkek işlerinden daha düşük ücret ve statü sunarlar (Ecevit, 1998: 278; Howe, 1978). Kısacası ilk çağlardan itibaren aklı ve tekniği erkeklikle özdeşleştirip üstün olarak niteleyen ataerkil ideoloji, vasıfların cinsiyetçi bir şekilde inşa edilmesine ve kadınların vasıflarının da, yaptıkları işlerin de değersiz görülmesine neden olmaktadır. Kadın emeğinin değersizleştirilmesi süreci, işgücü piyasasının hem yatay hem de dikey olarak cinsiyete göre ayrışmasında kendini gösterir (Hakim, 1979). Cam duvarlar (Urhan ve Etiler, 2011) olarak da adlandırılan yatay ayrışma, kadınların erkeklere oranla daha düşük ücret ve statü sağlayan mesleklerde yoğunlaşmalarını ifade ederken cam tavan olarak adlandırılan dikey ayrışma ise kadınların, kendileriyle aynı mesleği yapan erkeklere oranla daha düşük ücret ve statüyle çalışmalarını ifade 
eder (Hakim, 1979; Sinclair, 1991). Sağlık işgücü açısından cam duvarlar, kadınların doktorluk yerine hemşirelikte yoğunlaşmasına neden olur. Cam tavan ise, daha yüksek ücret ve statü sunan pozisyonlarda ve teknik alanlarda erkek hemşirelerin yoğunlaşmasında (Lou vd., 2007; Evans, 2004) ve kadın doktorların kadınlara uygun görülen, çalışma koşulları ağır olmayan, prestiji ve ücreti daha düşük olan uzmanlık alanlarına yönlendirilmelerinde (Bourdieu, 2014: 115; Urhan-Etiler, 2011) somutlaşır.

\section{Erkeklerin Hemşirelik Mesleğine Girişi}

Erkeklerin kadın yoğun mesleklere girmeleri için söz konusu mesleğin teknolojik gelişmelere konu olması, ücretinin ve statüsünün artması ve işgücü piyasasındaki diğer alternatiflerin azalması (Lindsay, 2007) gerekmektedir. Dünya genelinde erkeklerin hemşirelik mesleğine girişi 1970 sonrasında, hem hemşire açığının hem de işsizlik oranlarının artmasıyla birlikte hızlanmıştır (Meadus ve Twomey, 2007). Kadın yoğun mesleklere giren erkeklerin meslek içinde erkeklikle ilişkilendirilen alanlara yöneldikleri ve mesleği icra etmenin erkeksi yollarını aradıkları (Williams, 1993) ortaya konmuştur. Diğer bir deyişle hem erkeklerin mesleğe girmesi için mesleğin çeşitli açılardan dönüşmesi gerekmekte, hem de erkeklerin mesleğe girişi ile birlikte meslekte yeni dönüşümler gerçekleşmektedir. Erkeklerin genel olarak ücretli bakım işlerine girmelerinin bu işlerin toplumsal değerini artırabileceği (Acar-Savran, 2004: 65), hemşirelik mesleğine girmelerinin de mesleğin statüsünü artırabileceği (Şimşek-Rathke, 2011: 207; Waters vd., 1999) ileri sürülmektedir.

\subsection{Erkek Hemşirelerin Avantajları}

Erkekler, sayıca azınlıkta oldukları hemşirelik mesleğinde bile kadın meslektaşlarına oranla daha iyi görevlere getirilmekte, daha yüksek ücrete ve statüye sahip olmaktadırlar (Evans, 1997; Hader, 2005; O’Lynn ve Tranberger, 2006). Bu durumun nedenleri arasında kadınların gebelik ve doğum izni gibi nedenlerle tam zamanlı çalışmaya uzun süreli ara vermeleri, ailevi nedenlerle izin alma oranlarının yüksek ve coğrafi hareketliliklerinin düşük olması gösterilmektedir (Brown ve Jones, 2004). Erkek hemşirelerin ev ve aile ile ilgili sorumluluklarına kadınlardan daha az zaman ayırması, kadınlardan daha fazla deneyime, eğitime ve sertifikaya sahip olmalarını sağlayarak erkekleri avantajlı kılmaktadır (Brown ve Jones, 2004; Marsland vd., 2003). Ayrica erkek hemşirelerin kadın meslektaşlarına oranla daha fazla düzenli fiziksel etkinlik yaptıklarını, daha az stresli ve genel olarak daha sağlıklı olduklarını gösteren bulgular (Liminana-Gras vd., 2013) da söz konusudur. Bu bulgular erkeklerin 
ikinci vardiyadan (Hochschild ve Machung, 2012) azade olmalarından, diğer bir deyişle evle ilgili sorumluluklarının sınırlı olmasından kaynaklanmakta, böylece kadınlara oranla kendileri için kullanabilecekleri daha fazla zamana sahip olabilmektedirler. Dolayısıyla kadınların çalışma yaşamında ilerlemelerini sınırlandıran cam tavanın oluşmasına neden olan toplumsal cinsiyet eşitsizlikleri, erkekler için bir avantaja dönüşmektedir.

Meslek içinde erkeklere daha yüksek ücret ve statü sunan pozisyonların bir kısmı yöneticilik pozisyonlarıdır. Çeşitli çalışmalar (O'Lynn ve Tranberger, 2006; Hader, 2005), erkek hemşirelerin hemşirelikten çok hemşire yöneticiliğine yöneldiklerini ve yöneticilik pozisyonlarına kadın hemşirelerden daha hızlı eriştiklerini göstermektedir. Çalışmalar ayrıca genel olarak kadın yoğun mesleklerde çalışan erkeklerin, kendileri talep etmeseler bile üstleri ve meslektaşları tarafından, toplumsal cinsiyet normlarına uygun olduğu düşünülerek yönetici pozisyonlarına getirildiği gösterilmektedir (Taylor, 2010). Kadınların karşılaştıkları cam tavanın aksine, erkeklerin hızlı yükselme açısından sahip olduğu bu avantaj "cam asansör" kavramıyla (Williams, 1992) ifade edilmektedir.

Mesleğe erkeklerin girişinden önce de hemşirelik, kontrolün kadınların elinde olduğu bir meslek olamamıştır (Şimşek-Rathke, 2011: 52-53). Connell'ın (1998: 241) vurguladığı gibi, işyerlerindeki ilişkiler, işverenler ve çalışanlar arasındaki genel iktidar durumuyla koşullanır. Örneğin, genellikle erkek olan yönetici ile genellikle kadın olan sekreter arasında oldukça bireyselleşmiş olan karşılıklı bağımlılık ve güven ilişkisi, aslında belirgin gelir farklılıkları ve genelde bir bütün olarak erkeklerin toplumsal iktidarı ve otoritesi üzerinde temellenir (Connell, 1998: 242). Hemşirelik de bu çerçevede kuruluşundan itibaren büyük ölçüde erkeklerden oluşan doktorlar tarafından kontrol edilmiştir. Mesleğin kuruluşunda tıbbın kurduğu hegemonik iktidara dikkat çeken Gamarnikow'a (1978) göre modern hemşirelik mesleği, orta sınıf kadınlarına yarı profesyonel bir iş alanı açma karşı1lığında denetimin büyük çoğunluğunu erkeklere/doktorlara bırakmayı kabul etmiştir. Hemşirelik özgürleştirici bir kariyer olarak değil, kadınların madun statülerini sürekli kılacak bir meslek olarak görülmüş, hemşire imaj1, "güç ve nüfuzun tamamen zıttı" olarak inşa edilmiştir (Roberts ve Group, 1995: 194, 290-292). Hemşireler, hastanedeki erkek kontrolüne uyum sağlamayı mesleğe başlamadan önce, eğitim sürecinde öğrenmektedirler (Şimşek-Rathke, 2011). Bu açıdan erkek hemşirelerin mesleği icra etmek yerine hızlı bir şekilde yöneticiliğe yöneldiğini gösteren çalışmalar, meslekler arasında olduğu kadar meslek içinde de toplumsal cinsiyet temelli bir otorite ilişkisinin kurulmakta olduğuna dair işaretler olarak okunabilir. Zira cinsiyete dayalı işbölümünün ilkelerinden biri, bir kadının bir erkek üzerinde otorite uygulayamayacağı yönündedir ve tüm diğer koşullar sabitken "otorite gerektiren bir pozisyon söz konusu olduğunda, 
kadının bir erkeğin gerisine düşme ve daha ast asistanlık işlerini yüklenmesi ihtimali kuvvetlidir" (Bourdieu, 2014: 119). Hemşirelik mesleği içinde erkek otoritesinin artmakta olduğuna dikkat çeken Porter'ın (1992: 524) çalışması, erkek hemşirelerin otoritelerini kadın meslektaşlarının alan ve etkinliklerini sınırlamak amacıyla kullandıklarını ve kadın hemşirelerin mesleki konumlarını zayıflattıklarını göstermektedir. Türkiye bağlamında da kadın hemşireler, erkeklerin mesleğe girişiyle birlikte meslek içinde ataerkil bir işbölümü oluşabileceğine karşı özellikle uyarılmışlardır (Herdman ve Badir, 2008: 162; Tarihçi-Delice, 2006: 120).

Erkek hemşirelerin kadın meslektaşları üzerindeki otoritesi, Bourdieu'nun (2014) eril tahakküm ve sembolik şiddet kavramları üzerinden okunabilir. Bourdieu (2014), eril tahakkümün kadınların rızasına dayalı bir maduniyet habitusuna dayandığını ve kadınlar üzerinde sembolik şiddetin bu yolla işlediğini belirtir. Böylece erkeklerin kurduğu tahakküm sadece yapısal olarak algılanmaz, bireyler arasındaki etkileşimle meydana gelir ve yeniden üretilir. Bourdieu'ya (2014: 11-12) göre eril tahakküm, iktidara itaat etmenin örneklerinden biridir ve sembolik şiddet ile dayatılır. Sembolik şiddet, çoğunlukla iletişimin ve tanımanın, hatta hissetmenin saf sembolik kanallarıyla uygulanan, kurbanlarınca bile hissedilmeyen ve görülmeyen yumuşak bir şiddettir (Bourdieu, 2014: 11-12). Sembolik tahakküm bir dil, konuşma veya telaffuz biçimiyle ya da bir hayat tarzı ile yani tahakküm eden kadar edilenin de tanıdığı ve kabullendiği bir sembolik ilke adına uygulandığı için olağan bir toplumsal ilişki gibi kabul edilmektedir (Bourdieu, 2014: 12). Erkek hemşirelerin kadın meslektaşları üzerindeki otoritesi de zorlayıcı bir şekilde değil, ataerkil ideolojiyi içselleştirmiş olan kadınların doğal bir toplumsal ilişki olarak göreceği bir şekilde, sembolik tahakküm formunda ortaya çıkacaktır.

\subsection{Erkek Hemşirelerin Dezavantajları}

Erkek hemşirelerin meslekteki dezavantajlarının neredeyse tamamı toplum genelinde erkekliğin yaygın olarak kabul edilen biçimiyle, yani hegemonik erkeklikle (Connell, 1998) ilişkilidir. Hegemonik erkeklik normları, tüm kadınsı davranış ve özelliklerden kaçınmayı, başarı ve statü elde etmeyi, kendi ekmeğini kazanmayı, güçlü, güven duyulan ve bağımsız biri olmayı, ama aynı zamanda cesareti, saldırganlığı ve şiddeti (Atay, 2012: 16) vurgular. Bourdieu (2014: 68), cinsel veya toplumsal üreme becerisinin ötesinde, savaşma ve şiddet uygulama becerisi olarak da algılanan erkekliğin, bir görev olarak kabul edildiğini belirtmektedir. Görev olarak erkeklik, diğer erkeklerin önünde ve onlar için, kadınlığa karşıt olarak ve kişinin kendi içindeki bir tür dişil korku içinde inşa edilir (Bourdieu, 2014: 71). Bu nedenle hegemonik erkeklik kimliği inşa edilirken kadınsı addedilen nitelikler reddedilir ve dışlanır. 
Erkeklerin kendi aralarındaki otorite hiyerarşisi çerçevesinde de hegemonik erkeklik normlarına uymayan erkeklikler dışlanır ve ezilir (Connell, 1998: 153, 249). Diğer bir deyişle kadınları belirli kalıp yargıların içine yerleştirerek sömüren ve dışlayan sistem, kadınlar üzerinde kurduğu tahakkümü hegemonik erkeklik normlarına uymayan erkeklik biçimleri üzerinde de kurar (Connell, 1998: 245).

Hemşirelik mesleğinde vurgulanan fiziksel yakınlık, duygusal bakım, bağımlılık, şefkat ve özen gibi özelliklerin kadınlıkla ilişkilendirilmesi, hegemonik erkeklik bağlamında kadınsı olan her şeyden uzak kalmaya çalışan erkekler için bir çatışmaya neden olmaktadır. Hemşirelik mesleğini seçen erkekler, hegemonik erkeklik kimliğini zedeleyen (Dikmen-Özarslan, 2015), kadınlara mahsus olan ve görece düşük statülü bir mesleğe yöneldikleri için birer 'anomali' olarak görülebilmektedir (Battice, 2010). Bush'a (1976: 390) göre insanlar erkek hemşirelerin neden "daha düşük bir statüdeki cinsiyete özgü bir mesleği seçtiklerini" anlamakta zorlanmakta ve bu nedenle seçimlerine olumsuz yaklaşmaktadırlar. Hegemonik erkeklik kimliği ile meslek kimliği arasındaki bu çatışma, erkeklerin hemşirelik mesleğine girişinin sınırlı kalmasının nedenlerinden biridir (MacDouggal, 1997: 812; Meadus, 2000: 5; Dikmen-Özarslan, 2015: 135). Bu sınırlılık nedeniyle erkek hemşirelerin eğitim ve çalışma sürecinde örnek alacakları modellere ve etkileşim kuracakları meslektaşlara sahip olamadıkları, bu yüzden sosyal olarak izole oldukları (Smith, 2006) ve meslek içinde marjinalleştikleri (LaRocco, 2007) belirtilmekte ve bu durum da erkek hemşirelerin dezavantajları arasında sayılmaktadır.

Hegemonik erkekliğin saldırganlığı ve şiddet yönelimini vurgulaması, erkek hemşireler açısından sorun yaratmaktadır. Erkekliğin saldırganlıkla ve şiddetle ilişkilendirilmesi, kadın hastaların erkek hemşireleri saldırganlık potansiyeli taşıyan kişiler olarak görmelerine ve kadın hemşirelerle aynı şekilde dokunsalar bile dokunuşlarının fazla yakınlaşma olarak değerlendirilmesine neden olmaktadır (Chiarella ve Adrian, 2014). Çeşitli çalışmalara göre (Morin vd., 1999; Chiarella ve Adrian, 2014) bazı kadın hastalar erkek hemşirelerin dokunuşlarının özünde cinsel olduğunu düşünmekte ve erkek hemşirelerden bakım almayı reddetmektedirler (Harding, 2007; Poole ve Isaacs, 1997). Erkek hemşirelerin kendileri de kadın hastalara dokunuşlarının yanlış anlaşılmasından ve bu nedenle suçlanıp şikayet edilmekten endişe etmektedirler (Evans, 2002; Fisher, 2009). Erkekliğin şiddetle ilişkilendirilmesinin bir diğer boyutu da şiddete maruz kalan hemşirelerle ilgilidir. Erkek hemşirelerin kadın meslektaşlarına oranla daha fazla şiddete maruz kaldıklarını gösteren çalışmalar (Loughrey, 2008; Tracey ve Nicholl, 2007) bu durumu erkek hemşirelerin meslekteki dezavantajlarından biri olarak kabul etmektedir. Şiddet, hegemonik erkeklik kimliğinin ögelerinden biri olsa da bazı çalışmalar (Baby vd., 2014) erkek hemşirelerin şiddet içerikli olaylarla ilgilenmek için erkeklik temelli bir 
istek göstermediklerini ortaya koymaktadır. Benzer şekilde bazı çalışmalar (Bernard Hodes Group, 2005: 29; Hart, 2005: 33) erkek hemşirelerin kas gücünden ibaretmiş gibi algılanmaktan rahatsız olduklarını göstermektedir. Diğer bir deyişle hegemonik erkeklik normları, bu normları benimsemeyen erkek hemşireler açısından da sorun yaratmaktadır.

Hegemonik erkeklik normlarının erkek hemşireler açısından yarattı̆̆ bir diğer sorun, heteroseksüellik vurgusundan kaynaklanmaktadır. Connell (1998: 249) hegemonik erkekliğin heteroseksüellikle sıkı sıkıya bağlantılı olduğunu, bu nedenle eşcinsel erkekliğin tabi kılınmış, küçümsenen, taciz edilen bir erkeklik biçimi olarak görüldüğünü belirtmektedir. Çeşitli çalışmalar (Matthews, 2001; Wingfield, 2009; Harding, 2007; Brown, 2009) erkek hemşirelerin, bir kadın mesleği seçtikleri için eşcinsel veya efemine olarak damgalandıklarını, homofobik taciz ve alaylarla karşılaştıklarını göstermektedir. Fisher'ın (2009: 2672) bulgularına göre bazı erkek hemşireler eşcinsel olarak damgalanmamak amacıyla, hastalarla arabalar veya spor gibi erkeksiliği vurgulayan konularda ve eril bir dille konuşmakta, kendilerine bir 'maço' imajı yaratmaya çalışmaktadırlar. Bu durum eril ayrıcalıkların erkekler için tuzak haline gelebildiğini göstermektedir, Bourdieu'nun (2014: 69) belirttiği gibi erkekler, "her koşulda erkekliklerini ispatlamaya zorlayacak ölçüde abesleşebilen daimi bir gerilim ve çekişme" içindedirler. Hegemonik erkeklikten kendileri de mustarip olsalar bile erkekler "çaresizlik içinde erkeklik üretme durumunda" kalmaktadırlar (Atay, 2012: 18). Erkek hemşirelerin erkeklik kimliklerini pekiştirmek, savunmak ve yeniden üretmek zorunda hissettiklerini gösteren çalışmalar bu durumun batı toplumlarında olduğu kadar (Heikes, 1991; Fisher, 2009) doğu toplumlarında da (Zamanzadeh, 2013) gözlendiğini göstermektedir.

\subsection{Erkek Hemşireler Açısından Ataerkil Paradoks}

Ataerkil ideoloji ve hegemonik erkeklik, hemşirelik mesleğindeki erkekler açısından çelişkili sonuçlar doğurmaktadır. Hemşireliğin kadın yoğun bir meslek olmasına neden olan ataerki, mesleğe giren erkeklere yöneticilik yapma, hızlı yükselme, ücreti ve statüsü yüksek alanlarda çalışma gibi avantajlar sunmaktadır. Ancak aynı ideoloji, hegemonik erkeklik kimliğini desteklemekte ve erkek hemşireleri kadınsı nitelikler gerektiren pembe yakalı bir meslekten uzak tutmaya çalışmaktadır. Bu durumu "ataerkil paradoks" olarak adlandıran Kellett vd., (2014) erkek hemşirelerin mesleki konumlarını iyileştirebilmeleri için hemşirelik üzerindeki ataerkil etkiyi azaltmaya çalışmaları gerektiklerini belirtmektedir. Ayrıca hegemonik erkeklik normlarının şiddet, saldırganlık ve heteroseksüellik vurgusu erkek hemşirelerin bir yandan hastalara cinsel amaçlarla dokunacağı önyargısını, diğer yandan 
eşcinsel oldukları önyargısını üretebilmektedir. Bu açıdan erkek hemşirelerin bir ataerkil paradoks içinde sıkıştıkları ve mesleki avantajlarının ve dezavantajlarının iç içe geçtiği söylenebilir.

\section{Yöntem}

Çalışma, fenomenolojik desende tasarlanmış nitel bir alan araştırmasına dayanmaktadır ${ }^{1}$. Araştırma evreni aktif olarak çalışmakta olan hemşireleri kapsamaktadır. Türkiye'de 2013 itibarıyla 139.554 hemşire görev yapmaktadır (T.C. Sağlık Bakanlığı, 2014), ancak Türkiye genelinde aktif çalışan hemşirelerin cinsiyetine dair veriler kamuyla paylaşıılmamaktadır. Araştırma genelleme amacı taşımadığı için evreni temsil eden bir örneklem seçilmemiştir. Örneklem, olasılığa dayalı olmayan (yargısal) örneklem seçim tekniklerinden biri olan kota örneklem seçim tekniğiyle seçilmiştir.

Örneklem, tamamı aktif olarak çalışmakta olup, yarısı kadın yarısı erkek olan 42 hemşireden oluşmaktadır. Alan araştırmasına başlamadan önce örneklem büyüklüğü kesin bir sayıyla sınırlandırılmamıştır. Mülakatlar Eskişehir'de erkek hemşirelerle başlamıştır. Erkek görüşmecilerden birinin Urfa'daki mesleki deneyimleri hakkında verdiği bilgiler üzerine, Urfa'da erkek hemşire olma deneyiminin farkl11ıklar içerebileceği düşünülmüş, Eskişehir'de on erkek hemşire ile mülakat tamamladıktan sonra Urfa'da on bir erkek hemşire ile görüşülmüştür. Bulgularda tematik ve sistematik benzerlikler gözlenmeye başladığı için yirmi bir erkek hemşire yeterli görülmüştür. Daha sonra eşit sayıda kadın hemşire ile mülakat yapılmıştır. Kadın hemşirelerin tamamıyla Eskişehir'de görüşülmüştür. Urfa'da hiçbir kadın hemşireyle görüşülmemesi araştırmanın sınırlılıkları arasındadır. Tablo 1'de Aksaray ve Bursa'da çalışmakta olduğu görülen iki kadın görüşmeci Eskişehir'den son altı ay içinde taşınmış olan hemşirelerdir ve görüşmeler Eskişehir'de yapılmıştır.

Urfa'da görüşülen hemşirelerin tamamı bir özel hastanede çalışmaktadır, hastanede 500 hemşire çalışmaktadır ve 300'ü erkektir. Eskişehir'de 2015 itibarıyla kamu ve özel sağlık kurumlarında çalışan toplam 1754 hemşirenin \%7'si erkektir ${ }^{2}$, ancak hiçbir sağlık kurumunda Urfa'daki kadar yoğun erkek hemşire çalışmamaktadır. Örneklemdeki hemşirelerin çalıştıkları kurumlar ve birimler Tablo 1'de gösterilmektedir.

$1 \mathrm{Bu}$ araştırma, Anadolu Üniversitesi Bilimsel Araştırma Projeleri Komisyonu tarafindan 1505E453 No'lu proje olarak desteklenmiştir.

2 Eskişehir Kamu Hastaneler Birliği Müdürlüğü, Eskişehir Halk Sağlığı Merkezi, İl Sağlık Müdürlüğü ve özel hastane yetkilileri ile 09.09.2015 tarihinde yapılan görüşmeler sonucu elde edilen bilgi. 
Veriler, görüşmecilerle 2015 yılının Mart-Temmuz ayları arasında yapılan derinlemesine mülakatlarla toplanmış ve mülakatlar betimsel ve sistematik olarak analiz edilmiştir. En kısası 45, en uzunu 190 dakika süren mülakatlar sonucunda 52 saat 20 dakikalık ses kaydı elde edilmiştir. Mülakatlarda yapılan ses kayıtları için hemşirelerin onayı alınmıştır.

Örneklem Türkiye'deki tüm hemşireleri temsil etmemektedir, bununla birlikte görüşmelerin üçte ikisi bittiğinde verilen yanıtlarda sistematik tekrarlar gözlenmeye başlanmıştır. Bu açıdan benzer özellikler gösteren bağlamlar ve örneklemler söz konusu olduğu takdirde verilerin nitel araştırmalarda transfer edilebilirlik kriterini sağladığı söylenebilir. Bulgulara ilişkin yorumlar metin içinde görüşmecilerin kendi ifadeleri ile desteklenmiş, üç hemşire ile sözlü olarak paylaşılmış ve bu hemşireler tarafından onaylanmıştır. Bu bakımdan araştırmanın nitel araştırmalarda inandırıcılık ve doğrulanabilirlik kriterlerini yerine getirdiği söylenebilir.

Örneklemdeki erkek hemşirelerin çoğu meslek eğitimlerini Hemşirelik Kanunu'nda 2007 yılında yapılan değişiklik sonrasında almış olduğu için erkek hemşirelerin yaşları (ortalama 29) ve kıdemleri (ortalama 3 yıl) kadın meslektaşlarının yaşlarından (ortalama 39) ve kıdemlerinden (ortalama 19 yıl) düşüktür. Örneklemdeki hemşirelerin 15'i sağlık meslek lisesi, 7'si hemşirelik ön lisans, 20'si ise lisans mezunudur. Mesleki eğitimlerini farklı düzeylerde almış olmakla beraber, üçü dışında hepsi hemşirelik eğitimi almış, üç görüşmeci (G.2, G.6 ve G.7) ise sağlık memurluğu eğitimi almış ve 2007 y1lında hemşire kadrosuna atanmıştır.

Görüşmecilerin listesi ve demografik ve mesleki bilgileri Tablo 1'de gösterilmektedir. Metin içinde mülakatlardan yapılan alıntılarda görüşmecilere Tablo 1'deki numaraları ile referans verilmiş, alıntılarda geçen kişi isimleri değiştirilmiştir. 


\begin{tabular}{|c|c|c|c|c|c|c|c|c|c|c|}
\hline No & Cinsiyet & Doğum yeri & Yaş & $\begin{array}{l}\text { Medeni } \\
\text { hal }\end{array}$ & Ĕgitim & $\begin{array}{l}\text { Kudem } \\
(y u l)\end{array}$ & Çalıştığı birim & Çalıștiğı sektör ve il & Baba mesleği & Anne mesleği \\
\hline G.1 & Erkek & Kır, Eskişehir & 21 & Bekâr & Sağlık Meslek Lisesi & 3 & Acil & Özel, Eskişehir & Esnaf & İşçi \\
\hline G.2 & Erkek & Kent, Eskişehir & 34 & Evli & Sağlık Meslek Lisesi & 9 & Ameliyathane & Devlet, Eskişehir & Esnaf & Ev kadını \\
\hline G.3 & Erkek & Kent, Ankara & 27 & Bekâr & Lisans & 3 & Üroloji & Devlet, Eskişehir & Esnaf & Ev kadını \\
\hline G.4 & Erkek & Kent, Eskişehir & 19 & Bekâr & Sağlık Meslek Lisesi & 1 & Yoğun bakım & Özel, Eskişehir & İşçi & Ev kadını \\
\hline G.5 & Erkek & Kent, Kütahya & 24 & Bekâr & Lisans & 3 & Yoğun bakım & Tip Fak, Eskişehir & Esnaf & Ev kadını \\
\hline G.6 & Erkek & Kır, Afyon & 36 & Evli & Sağlık Meslek Lisesi & 9 & Ameliyathane & Devlet, Eskişehir & Çiftçi & Ev kadını \\
\hline G.7 & Erkek & Kır, Niğde & 35 & Evli & Sağlık Meslek Lisesi & 9 & Psikiyatri & Devlet, Eskişehir & Çiftçi & Ev kadını \\
\hline G. 8 & Erkek & Kır, Van & 28 & Bekâr & Lisans & 2 & Yoğun bakım & Tip Fak, Eskişehir & Çiftçi & Ev kadını \\
\hline G.9 & Erkek & Kır, Adana & 25 & Bekâr & Lisans & 2 & Yoğun bakım & Tıp Fak, Eskişehir & Çiftçi & Ev kadını \\
\hline G. 10 & Erkek & Kır, Adıyaman & 25 & Bekâr & Lisans & 1 & Onkoloji & Özel, Urfa & Esnaf & Ev kadını \\
\hline G.11 & Erkek & Kır, Adıyaman & 24 & Bekâr & Lisans & 1 & Dahiliye & Özel, Urfa & Çiftçi & Ev kadını \\
\hline G.12 & Erkek & Kır, Kahramanmaraş & 25 & Bekâr & Lisans & 1 & Yeni doğan & Özel, Urfa & Mevsimlik işçi & Ev kadını \\
\hline G.13 & Erkek & Kır, Kahramanmaraş & 20 & Bekâr & Sağlık Meslek Lisesi & 1 & Onkoloji & Özel, Urfa & Çiftçi & Ev kadını \\
\hline G.14 & Erkek & Kır, Kahramanmaraş & 20 & Bekâr & Sağlık Meslek Lisesi & 2 & Kardiyoloji & Özel, Urfa & Çiftçi & Ev kadını \\
\hline G.15 & Erkek & Kır, Adıyaman & 29 & Bekâr & Lisans & 6 & Kardiyoloji & Özel, Urfa & Çiftçi & Ev kadını \\
\hline G.16 & Erkek & Kır, Şırnak & 25 & Bekâr & Ön lisans & 2 & Yoğun bakım & Özel, Urfa & Çiftçi & Ev kadını \\
\hline G.17 & Erkek & Kır, Adıyaman & 26 & Bekâr & Lisans & 2 & Yoğun bakım & Özel, Urfa & Çiftçi & Ev kadını \\
\hline G.18 & Erkek & Kır, Urfa & 25 & Bekâr & Lisans & 1 & Ameliyathane & Özel, Urfa & Çiftçi & Ev kadını \\
\hline G.19 & Erkek & Kır, Urfa & 27 & Bekâr & Lisans & 1 & Ameliyathane & Özel, Urfa & Çiftçi & Ev kadını \\
\hline G.20 & Erkek & Kır, Urfa & 26 & Bekâr & Lisans & 1 & Yoğun bakım & Özel, Urfa & Çiftçi & Ev kadını \\
\hline G.21 & Erkek & Kır, Urfa & 24 & Bekâr & Lisans & 2 & Yeni doğan & Devlet, Eskişehir & Çiftçi & Ev kadını \\
\hline G.22 & Kadın & Kır, Sivas & 46 & Evli & Sağlık Meslek Lisesi & 29 & Hasta hakları & Devlet, Eskişehir & İşçi & Ev kadını \\
\hline G. 23 & Kadın & Kent, Eskişehir & 37 & Bekâr & Lisans & 20 & İntaniye & Devlet, Eskişehir & Esnaf & Ev kadını \\
\hline
\end{tabular}




\begin{tabular}{|c|c|c|c|c|c|c|c|c|c|c|}
\hline G.24 & Kadın & Kır, Bilecik & 41 & Evli & Sağlık Meslek Lisesi & 21 & Göğüs hastalıkları & Devlet, Eskişehir & Memur & Ev kadını \\
\hline G.25 & Kadın & Kır, Ankara & 39 & Evli & Sağlık Meslek Lisesi & 22 & Palyatif bakım & Devlet, Eskişehir & Çiftçi & Ev kadını \\
\hline G.26 & Kadın & Kent, Bulgaristan & 61 & Evli & Ön lisans & 36 & Palyatif bakım & Devlet, Eskişehir & Maden işçisi & Ev kadını \\
\hline G.27 & Kadın & Kır, Ankara & 37 & Evli & Sağlık Meslek Lisesi & 14 & Palyatif bakım & Devlet, Eskişehir & Çiftçi & Ev kadını \\
\hline G.28 & Kadın & Kır, Bulgaristan & 41 & Evli & Lisans & 19 & Palyatif bakım & Devlet, Eskişehir & İşçi & İşçi \\
\hline G.29 & Kadın & Kır, Yozgat & 47 & Evli & Sağlık Meslek Lisesi & 27 & Palyatif Bakım & Devlet, Eskişehir & İşçi & Ev kadını \\
\hline G.30 & Kadın & Kent, Eskişehir & 43 & Boşanmış & Ön lisans & 25 & Ortodonti & Devlet, Eskişehir & Memur & Ev kadını \\
\hline G.31 & Kadın & Kent, Kırıkkale & 44 & Evli & Sağlık Meslek Lisesi & 25 & Palyatif bakım & Devlet, Eskişehir & Esnaf & Ev kadını \\
\hline G.32 & Kadın & Kent, Bilecik & 36 & Evli & Lisans & 13 & Palyatif bakım & Devlet, Eskişehir & Memur & Ev kadını \\
\hline G.33 & Kadın & Kır, Aksaray & 25 & Evli & Lisans & 3 & Kardiyoloji & Devlet, Aksaray & Çiftçi & Çiftçi \\
\hline G.34 & Kadın & Kır, Eskişehir & 21 & Bekâr & Sağlık Meslek Lisesi & 4 & Yeni doğan & Tip Fak., Eskişehir & Çiftçi & Ev kadını \\
\hline G.35 & Kadın & Kent, Bursa & 22 & Bekâr & Ön lisans & 3 & Yoğun bakım & Özel, Bursa & İşçi & Serbest meslek \\
\hline G.36 & Kadın & Kır, Ankara & 37 & Evli & Sağlık Meslek Lisesi & 18 & Pediatri & Devlet, Eskişehir & Çiftçi & Ev kadını \\
\hline G.37 & Kadın & Kent, Eskișehir & 41 & Evli & Ön lisans & 23 & Halk Sağlığ 1 & Devlet, Eskişehir & Memur & Ev kadını \\
\hline G.38 & Kadın & Kent, Eskişehir & 36 & Bekar & Ön lisans & 14 & Pediatri & Devlet, Eskişehir & Memur & Ev kadını \\
\hline G.39 & Kadın & Kent, Kütahya & 35 & Bekar & Lisans & 15 & Pediatri & Devlet, Eskişehir & İşçi & Ev kadını \\
\hline G.40 & Kadın & Kent, Eskişehir & 44 & Evli & Lisans & 26 & Fizik ted. ve reh. & Devlet, Eskişehir & İşçi & Ev kadını \\
\hline G.41 & Kadın & Kent, Eskişehir & 43 & Evli & Ön lisans & 25 & Nöroloji & Devlet, Eskişehir & Memur & Ev kadını \\
\hline G.42 & Kadın & Kent, Eskişehir & 39 & Evli & Ön lisans & 19 & Palyatif bakım & Devlet, Eskişehir & Memur & Ev kadını \\
\hline
\end{tabular}




\section{Bulgular}

Mülakat deşifreleri sistematik olarak incelenmiş, görüşmecilerin erkek hemşire olma deneyimi hakkındaki anlatıları, literatürde erkek hemşirelerin avantajları ve dezavantajları olarak belirtilen temalar çerçevesinde analiz edilmiştir. Bu temalar (i) erkeklerin mesleğe getirdiği otoriterlik, (ii) fiziksel farklılıkların avantaja dönüşmesi, (iii) cinsiyete dayalı ev içi işbölümünün etkisi, (iv) erkeklik ve yöneticilik arasında kurulan ilişki, (v) mesleki azınlık olmanın yarattığ izolasyon, (vi) kadın hastalara dokunma konusunda kaygılar ve (vii) cinsel kimliğin sorgulanmasıdır.

\subsection{Erkeklerin Mesleğe Getirdiği Otoriterlik}

Örneklemdeki tüm hemşireler, erkek hemşirelerin doktorlarla, hastalarla ve hasta yakınlarıyla kadın meslektaşlarına oranla daha otoriter ve sert ilişkiler kurduklarını belirtmiştir. Erkek hemşirelerin hegemonik erkeklik kaynaklı bu otoriter ve sert tavırları, görüşmecilerin hepsine göre mesleği güçlendirecek ve mesleki statüyü yükseltecek bir etkendir. Meslekler arası otorite ilişkilerini sorgulayan erkek hemşireler, aşağıdaki alıntılarda görülebileceği gibi doktorların otoriter ve incitici tavırlarından, "uysal" kadın hemşireleri sorumlu tutmakta ve erkek hemşirelerin sayıca artmasıyla birlikte bu durumun değişeceğini öngörmektedirler:

"Özellikle mesela erkek hemşire olmadan önce bayan hemşirelere, yani hani azarlama olsun, iş yükü açısından yüklenme olsun hani bu konularda farklı davrandıkların düşünüyorum. Mesela o da bayanların neyden olabilir, bayanların gerçekten bayan hemşirelerin hani cevap vermemeleri, tepki vermemeleri. ... Hani bir erkek bir olur, iki olur, üç olur, dört olur artık belli bir şeyden sonra tepkisini ortaya koyar. Hani zaten doktor da verdiği tepkiye karşıllk tepki göreceğini düşündüğü için belki şeyi, o tavrı sürdürmez." (G.11)

“... Bizim bayan hemşireler de işi bu duruma getirmişler. Doktor ne derse doğrudur mantı̆̆ gelmiş. Doktor ne derse doğrudur, hâlbuki öyle bir şey yok. Hani, gerekirse hani illa hani şeydir, kavga mahiyetinde ... yani bizim geçmişten geleceğe süren bir şey, bayan artık evet hocam, efendim hocam, tamam hocam, öyle hocam, böyle hocam diye diye aslinda her şeyi bize yüklemişler" (G.12)

"Erkek saylsı arttıkça şey olacak. [Erkek hemşire] bırak hemşireyi doktoru azarliyor. Ben erkek olduğum için baskınlığımı yapabiliyorum. Bir olay saçma sapan bir şeydir, bayan hemşire söyleyemez. Çünkü bayan olduğu zaman karşıllk verir. Ben söylediğim zaman bana karşıllk vermeye biraz daha çekingenlik. Bayanları istediği gibi 
azarlayabiliyorlar mesela. Açıkçası bizden biraz korkuyorlar diyeyim. Bu da zamanla saygınlı̆̆ oluşturacak diye düşünüyorum. ” (G.8)

"İşte doktor bă̆ırır çağırır ameliyatta ters davranır bilmem ne yapar, hemşirenin gücü ağlamaya yetiyor. ... iş erkek erkeğe geldiği zaman. ... Ha şöyle bir şey var toplumda, bayana yüklenirsin, trafikte de öyle, korna çalarsın sıkıştırırsın bilmem ne yaparsın, bayan telaş eder, kaza yapar ya ă̆lar ya durur bekler. Ama erkeğe yaptı̆̆ın zaman nedir, ne olacă̆ını bilemezsiniz. Kavga edebilirsiniz, çekip vurabilir, daha sizden şey biri çıkabilir. O yüzden kimse erkek erkeğe pek takışmaz.” (G.7)

Porter (1992) erkek hemşirelerin meslekler arası otorite ilişkilerini değiştirmeye çalışmadığını ve doktorlara karşı kadın hemşirelerden daha otoriter tavırlar takınmadıklarını savunmuştur, ancak bu çalışmada aksi yönde bulgular elde edilmiştir. Yukarıdaki alıntılarda görüldüğü gibi, erkek hemşireler eril dil bir kullanarak bir yandan kadın hemşireleri değersizleștirmekte, diğer yandan meslekler arası otorite ilişkilerine de tepeden bakan bir söylem inşa etmektedir.

Erkek hemşireler, aşağıdaki alıntılarda görülebileceği gibi, hastaları disipline edecek bir iktidar aracı olarak da görülmektedir. Hastaların erkek hemşirelerin otoriter tavırlarından etkileneceği ve hemşirelerle olan ilişkilerinde daha disiplinli ve itaatkâr olacakları öngörülmektedir:

“Hastaya sözünü geçirmesi lazım. ... Karşısındaki bayan olduğu için onu biraz daha zaylf mı görüyor desem. Hani dedim ya biraz da güç meselesiyle alakalı, ne yazık ki bu böyle yani. Sonuçta bir bayan bir erkek kadar güçlü değil. Hani gittiği zaman bayanı biraz daha pasif görüyor erkeğe oranla. Erkek söylediği zaman tamam, bir de ciddi söylediği zaman sonuçta sesten bile etkilenebiliyor yani. Bayan biraz daha kibar konuşur ama erkek kibar konuşmaz o kadar kolay.” (G.17)

"Bir kere hasta disiplini de daha kolay oluyor erkeklerle çalıştı̆̆ınızda. Hasta çok laubali olamıyor sizinle. ... bizde bayan hasta çok olduğu için, erkek hemşire varsa böyle bir çekinme olaylar vardır, konuşmama olayları vardır. Ĕger seni iki dakika yalnı gördüyse hemen gelir ya çocuğunu anlatır ya kocasını, kayınvalidesini anlatır... Yani bizimle iletişimleri kolay olduğu için. Ama erkeklere her şeylerini söyleyemedikleri için biraz daha disiplinli bir yaklaşımları oluyor." (G.22)

Görüşülen hemşireler, hasta ve hasta yakınları üzerinde kurulması gerektiğini düşündükleri otoriteyi, sıklıkla hemşirelere yönelik şiddetle ilişkilendirmektedirler. Şiddet, yurt dişındaki çalışmalarda erkek hemşirelerin dezavantajlı olduğu konulardan biri olarak vurgulanmakta ve çeşitli çalışmalar erkek hemşirelerin fiziksel şiddete (Loughrey, 2008; Tracey ve Nicholl, 2007), 
duygusal ve cinsel taciz ve saldırılara (Andrews vd., 2012) kadın hemşirelerden daha fazla maruz kaldıklarını göstermektedir. $\mathrm{Bu}$ çalışmanın bulgularında durum aksidir; yirmi bir erkek hemşirenin beşi, yirmi bir kadın hemşirenin ise on beşi hasta veya hasta yakınlarından fiziksel veya sözlü şiddete maruz kalmıştır. Üç kadın hemşire, hastalar tarafından elle dokunma yoluyla cinsel tacize maruz kaldığını belirtmiştir. Bu hemşirelerin biri dâhil olmak üzere üç kadın hemşire de hasta ve hasta yakınlarının kendileriyle aşağılayıcı tavırlarla konuştuklarını ve gereksiz olduğu halde kendilerini sürekli çağırarak psikolojik olarak yıprattıklarını, dolayısıyla duygusal tacize maruz kaldıklarını ifade etmişlerdir. Şiddete veya tacize maruz kalma oranlardaki büyük farkl1lık kısmen örneklemdeki erkek hemşirelerin yaş ve kıdem ortalamalarının kadın meslektaşlarından daha düşük olmasından kaynaklanıyor olabilir. Bununla birlikte örneklemdeki 42 hemşirenin 39'u şiddet gösterme eğiliminde olan kişilerin, karşılık göreceklerini düşündükleri için erkek hemşirelere yönelmeyeceklerini, bu nedenle kadın hemşirelerin şiddete maruz kalma riskinin daha yüksek olduğunu düşünmektedir. Bu konuda bazı hemşirelerin görüşleri aşağıdaki gibidir:

"Kadına kesinlikle daha fazla, hani bizde erkek egemen bir toplum olduğu için, normalde eşine de şiddet gösteriyorsa, hastanedeki hemşireyi de aynı o pozisyonda görüyor ve sanki bağırarak çağırarak ya da şiddet uygulayarak onu her türlü sindirebileceğini düşünüyor. Ama erkek hemşireye hani biraz daha, gücünün yetmeyeceğini biliyor. Ona o kadar cesaretle söyleyemiyor her şeyi." (G.33)

"Kadınlar daha risk altında. ... duyuyorum hani şu hasta bana şöyle dedi şu bana böyle dedi böyle yaptı diye, kadın hemşirelere çok şey yapıyor hastalar. O hastaya ben gittiğim zaman bana hiçbir şey demiyor hani. ...

Onlara [kadın hemşirelere] daha fazla söz geçirebileceklerini düşünüyorlar." (G.3)

"Erkeklere biraz zor. Örnek vereyim. Hasta yakınları kapının önünde, [kadın hemşire] beyefendi giremezsiniz diyor. Görüp çıkacam diyor, tartışıyor. ... hemşire arkadaş susuyor ve çekiliyor. Ben gidiyorum, beyefendi çıkar mısınız diyorum. Hiç ikinci cümle yok çıkarken. Erkek olması yetiyor. Erkek olunca sözü dinleniyor. Bayan olunca sözü dinlenmiyor. " (G.8)

"Hastanede bire bir sürekli temas halindesiniz. ... Mesela bir erkek geliyor. Urfa'nın biliyorsunuz kültürel yapısını. Gelip de bi bayana bă̆ırıp çă̆ırınca bayan susuyor, gidip ă̆layabiliyor. Ama erkekte o şekilde olmuyor, Urfa gibi bir yerde erkek daha avantajlı yani.” (G.14) 
Urfa'da çalışan erkek hemşireler Urfa'daki kültürel bağlama sıklıkla göndermede bulunmaktadırlar. $\mathrm{Bu}$ göndermeler genellikle korumac1 cinsiyetçilik üzerinden kadınların yaşam veya çalışma alanının sınırlanması temasını içermektedir:

“... biliyorsunuz burda aşiret durumu var. Bi hastanın günde üç yüz tane yakını geliyor. Ben o üç yüz tane yakınından sadece birini alıyorum içeri. İkincisini alma şansim yok. Illa ki olay oluyor yani. ... Ameliyat oluyor, ameliyatta hasta dönmüyor, eks oluyor. ... Dönmediği için doktor merdivenlerden kaçmak zorunda kaldı mesela. Diğerleri de kapıyı, pencereyi kırdılar. Aşiret durumundan ötürü Urfa'da bu durum çok sıkıntı, dağıtıyorlar yani. Yani erkek de olsa bayan da olsa yapacak bir şey yok belki ama bir bayanın bu şeyde ne işi var bu karışılklkta diyebilirsiniz yani” (G.14)

"Ben [şiddete] maruz kalmadım da arkadaşlarımdan bayağı maruz kalan oldu yani. Yani mesela hastayla ilgili, mesela göstermedin, ya da mesela eks oldu, her şey olabilir. Böyle biraz daha güneydoğu şey olduğu için, insanlar hemen işte Ali 'yi çağır Ahmet'i çağır on kişi ordan gelir, on kişi burdan gelir, gerisi de gelir. ... Siz tabi bunu göremezsiniz de, çünkü Eskişehir daha farklı bir yer. Orda her şey konuşulur ama burda adam direk bıçak çıkarır, silah çıkarır falan yani." (G.20)

"[Kadın hemşirelerin] çalışabileceği yer var, çalışamayacağl yer var şimdi. Yani Urfa'da, yoğun bakımda hasta mesela eks oldu diyelim. Hasta yakını o psikolojiyle her şeyi yapabilir. Biz araya girmeyiz. Yani erkekler bile girmez. Çünkü o anda her şeyi yapabilir.” (G.16)

Örneklem genelinde erkek hemşirelerin otoriter tutumları hakkındaki ifadelerde kadınların fiziksel olarak erkeklerden daha "savunmasız" olduğu vurgulanmış, erkek bedeni, kas gücü gibi biyolojik farklılıklara dayanılarak avantajlı bir beden olarak kurgulanmıştır.

\subsection{Fiziksel Farklılıkların Avantaja Dönüşmesi}

Kadın hemşirelere göre erkek hemşirelerin en önemli avantajı kas gücüdür ve bu bakımdan erkek hemşirelerin istihdamı işlevseldir. Aşağıdaki alıntılarda örnekleri görülebileceği gibi bu durum kadın hemşireler tarafından sıklıkla vurgulanmaktadır:

“...Çünkü hemşirelik meslek olarak ağır bir meslek. Çünkü atıyorum siz elli kilosunuz yüz kiloluk hastaya solüsyon vermeniz gerekiyor. Ya da çevirmeniz gerekiyor. Hani klinikte şu an on iki hemşireyiz biz ama bel fitığl olmayan arkadaşım yok. Ya da işte kolu bacă̆ ăgrımayan arkadaşım yok.” (G.24) 
"Hastalara pozisyon verdirmek açısından, kaldırmak, döndürmek açısından yani, daha rahat kaldırma şanslart var. Mesela şimdi sonuçta iki bayan [nöbet] tutuyoruz. İkimiz yapcaz. Hani şey olsa, burda bir erkek arkadaş olsa, o zaten senden önce hani ben gideyim kaldırayım hastayı diye o yardımcı olmaya çalışır. Yani bir kere ben direk yanıma bir tane erkek hemşireyle çalışmayı daha çok tercih ederim." (G.22)

Erkek hemşireler de kadın hemşireler gibi kas gücünü sıklıkla vurgulamaktadırlar. Hemşirelerle ilgili çalışmalarda erkek hemşirelerin meslekteki işbölümü nedeniyle sıklıkla kas gücüne indirgendiklerini hissettikleri ve bundan rahatsız oldukları (Bernard Hodes Group, 2005: 29; Hart, 2005) belirtilmektedir. Bu çalışmada ise erkek hemşireler kas gücünü bir yandan otoriter davranışları ve erkek iktidarını "mümkün kılan" bir potansiyel olarak, diğer taraftan hemşirelik mesleğinde istihdam edilmelerinin gerekçelerinden biri olarak görmektedirler. $\mathrm{Bu}$ nedenle kas gücüne "indirgenmiş" hissetmemekte, aşağıdaki alıntılarda görülebileceği gibi durumu eril bir dille ifade etmekte, kendilerinin "zayıf ve güçsüz" kadınlardan üstün olduklarını vurgulamaktadırlar:

“... Hasta çekiliyor, erkeksen çek al o tarafa, hasta var 140 kilo. Solunum cihazı bağlanmış, kritik yani, onun sallanmaması lazım. Çıkabilir her an. Çıkarsa gitti. Bunlar daha önce yaşanmış şeyler. Erkek olduğun zaman elini atabiliyorsun hemen. Ama kız elini atmıyor. Atsa bile bir işe yaramiyor. Personeli bekliyor. Atabilen kimse yok. Doktor bayan, hemşire bayan, yapamıyorlar, atamıyorlar. Erkek gelmesi lazım oraya." (G.8)

“... Mesela hastayı almak için işte çevreden hasta yakını, refakatçilerini falan çă̆ırmak zorunda kalıyorlar mesela ben olmadı̆̆ım zaman bayan arkadaşlar. Hani onların yardımıyla hastayı şeye taşıyoruz. ... Yoğun bakımlarda hastanın hani banyo yaptırılması ya da temizliği, çarşaflarının değişmesi, hastayı döndür, çevir, gene bir kas gücü istiyor." (G.3)

"Mesela acil bir hasta geliyor, kurumlarda, kapının önüne arabayla yanaştırtyorlar, baygın bir şekilde onu oradan alıp sedyeye koymak gerekiyor, onu kızlar yapamıyor. Senin yapman lazım. ... Erkek hemşireler yokken de hastalar yardım ediyordu." (G.1)

Erkek hemşirelerin kas gücünün daha yoğun olduğu, daha "eril" alanlarda çalışmak istemeleri, hemşireliğin kadınsı olan bakım işlerinden, yani mesleğin kadınsı yanından uzaklaşmak için kullandıkları stratejilerden biri olarak değerlendirilmektedir (Evans, 2002, 2004; Fisher, 2009; Inoue vd., 2006; Gönç, 2016). Bu açıdan erkeklerin fiziksel farklılıkları kendileri için bir 
avantaja dönüşmekte ve erkeklerin daha çok ameliyathane, yoğun bakım, ortopedi gibi alanlarda yoğunlaşabileceği muhtemel bir meslek içi işbölümünün zeminini oluşturmaktadır.

\subsection{Toplumsal Cinsiyete Dayalı Ev İçi İşbölümünün Etkisi: “Evde Bekleyen İşler"}

Örneklemdeki hemşireler erkek hemşirelerin fazla mesaiye ve gece nöbetlerine kalabilme, geç saatlerdeki ya da uzak mekânlardaki toplantı, eğitim ve seminerlere katılabilme ve doğum ve gebelik gibi nedenlerle bölünmeyen istikrarlı bir çalışma yaşamı sürdürebilme konusunda avantajlı olduklarını ve bu sayede meslekte yükselmelerinin kadın meslektaşlarına oranla daha kolay olduğunu vurgulamışlardır:

“Çünkü bayan hemşireler belli bir yaştan sonra hamilelik geliyor, belli bir süre sonra mesela birakıyor. Erkeğin öyle bir şansi yok. Erkek çalışıyor. Kadınlar .. otuz yaşından sonra, bırakacă̆ım ben bu mesleği, çocuk var falan der birakır.” (G.16)

"Çünkü [erkekler] daha disiplinli olur, daha düzenli olur. Isşe zamanında gelip gitmede hiç bir sıkıntısı olmaz. Gece yetişmesinde, erken çımasinda, zamanında gelip, zamanında gider. Bayanın öyle bir şansı yoktur. Ya çocuğu vardır erken çıkabilir, hasta olur. ... Hani erkek olursa avantajı daha yüksek olur yani, hani her konuda. Isste nasıl diyeyim, toplantı yapılmasinda, toplantınin zamaninı belirlemesinde hani her saatte ben gelebilirim, ama bayan öyle değil. Ya, bayan gece eve gidecektir. Çocuklarina bakacaktır. Diyemez ki ben saat sekizde şu kafede, şurada arkadaşlar toplantı yapalım, onu diyemez yani" (G.10)

“... ileride erkek yönetici artar diye düşünüyorum. Yarl yarıya muhakkak, belki daha fazla, çünkü bayan eve bakmakla yükümlüdür bizim Türkiye'de." (G.17)

"Hani kadının toplumumuzda aile görevi de oluyor. Hani mesela yemek yapma, işte evin düzeni, çocuk bakımı olsun bi de nöbete geliyorlar buradaki kadın hemşirelerin her birinin hayatları öyle karmaşık ki. Buradan çıkıyorlar, kocasının ailesi gelmiş yemek yapmak zorunda kallyor. Şey oluyor, çocuğu ateşleniyor, gece nöbete gelemiyor hani... Erkekler biraz daha bunu şey yapabiliyor. Kadınların biraz daha ailedeki görevleri önemli ..." (G.3)

Kadın hemşireler erkeklerin bu konuda avantajlı olduğunun ve ev içi sorumluluklarının kendileri için yapısal bir engel oluşturduğunun farkındadır. $\mathrm{Bu}$ farkındalığa rağmen kadın hemşirelerin büyük çoğunluğu cinsiyete dayalı ev içi işbölümünü doğal karşılamakta ve cam tavanı içselleştirmektedir. Ancak 
küçük bir kısmı, toplumsal cinsiyete dayalı işbölümü nedeniyle ayrımcılıkla karşılaştıklarını vurgulamakta, aşağıdaki alıntılarda görülebileceği gibi cam tavanı görmekte ve bundan rahatsı olmaktadır:

"İste kadındır, çoluğu çocuğu vardır, ya hamile kalıyor, işte işten uzak kalıyor, biz gece toplantı yapıyoruz o gelemiyor, tercih edilmeme sebepleri. ... ya biz işte akşam toplanıyoruz geç saate kadar çalışıyoruz. Atıyorum Ayşe Hanım bu iş için uygun değil. Niye, Ayşe Hanım gelemez, Ayşe hanım hamile, Ayşe hanımın çocuğu var. Onu hemen bir ayırma oluyor. Erkekler daha sanki özgürmüş gibi değerlendirilip işlerde görevlendirilmesi erkeklerde daha çok yapıllyor” (G.31)

"Kadınların sorumluluğu daha çok çünkü evde çocuklarıyla da ilgileniyor. $O$ diyor ki yani işimi yapayım gideyim, farklı şeylerle uğraşmayayım. Ama erkeklerin kariyer yapmak için uğraşacak zamanları var. Okuyabilirler. Kariyer yapmak için uğraşabilirler. Ama kadınlar öyle değil ki. Evde çocukla uğraşıyor, buraya geliyor nöbetiyle uğraşlyor, işiyle uğraşıyor. Ondan sonra gidip de ben kariyer için uğraşayım, okuyayım, seminere gideyim, işte sertifika alayım gibi bir şey içine giremiyorlar. Ataerkil toplumlarda öyledir yani. Erkekler her zaman kendilerine daha fazla zaman ayırabilirler. Kendileri için daha fazla şey yapabilirler. Evde yapmaları gereken şeyler yok. Tabi onun yerine zaten kadın yapıyor bunu. Ona sadece terfisi kalıyor, eğer terfi etmek istiyorsa. $\ddot{U}$ ç tane çocuğum var. Tabi evde onlarla ilgileniyorum. Yaşll annem var, oğlan kardeşim var özürlü. Hani ben nasıl bir kariyer yapabilirim ki bu durumda?" (G.30)

İşbölümü üzerinde kadınlardan daha fazla denetime sahip olan erkeklerin çocuk bakımı işlevini üstlenmeme yönündeki ortak seçimleri, erkeklerin çıkarının egemen tanımını yansıtmakta ve egemen gücü korumalarına yardımcı olmaktadır (Connel, 1998: 149). Çocuk bakımı ve ev içi işlerin kadınlara aktarılması erkeklerin güçlerini ve avantajlarını korumalarını sağlarken, kadınlar için bazı meslek ya da alanlardan dışlanmaya (Urhan-Etiler, 2011) neden olabilmektedir. England (1993) ev işlerine zaman ayırmak isteyen kadınların kısmi süreli ve düşük ücretli işlerde çalışmaya razı olduklarını, böylece kadın emeğinin ücretinin düşük tutulabildiğini göstermektedir. $\mathrm{Bu}$ çalışmadaki bulgular da ev işlerinden, çocuk ve yaşlı bakımından kadınların sorumlu tutulması sürdükçe diğer pek çok meslekte olduğu gibi hemşirelik mesleğindeki erkeklerin kadın meslektaşlarına göre meslekte ilerleme açısından avantajlı olacaklarını göstermektedir. 


\subsection{Erkeklik ve Yöneticilik Arasında Kurulan İlişki}

Örneklemdeki hemşirelerin tamamına yakını toplumsal cinsiyet kalıp yargıları çerçevesinde erkeklerin "doğuştan" soğukkanlı olduklarını, "kadınlar gibi duygusal" olmadıklarını belirtmiştir. Görüşmecilerin büyük çoğunluğu eril bir dil ve söylem içinde kadın ve erkeği zıt kategoriler olarak kurgulamakta, buna dayanarak erkek hemşirelerin kadın hemşirelerden daha iyi yöneticiler olacağını ve gelecekte hemşirelik mesleğindeki yönetici kadroların büyük çoğunlukla erkek hemşireler tarafından doldurulacağını düşünmektedir:

“..erkekler olaylara duygusal yaklaşmıyorlar, bayanlar duygusal yaklaşlyorlar genellikle ... Erkekler daha az duygusal karar vermede. Yani duygusallıktan kaynaklanan bir şey. Doğru karar veremiyorlar bazen. Mesela hasta sizinle bağırarak konuşuyor böyle ters durumlarda, duygusallı̆̆a kapılıp ă̆layanlar var, durumu nakledemeyenler var, anlatamayanlar var hastalara. Sakin olamıyorlar bu konularda, çok fark ediyor yani. En önemlisi bu bence, çoğu ă̆layıp gidiyor yani. Genel olarak dayanıklılık olarak erkekler daha güçlü.” (G.1)

“...Yani bence bu, yönetim işini erkeklerin daha iyi beceriyor olmasından kaynaklanıyor. Ki bu, genelde hemşirelik içinde geçerli değil ki, her yerde çoğunlukla yönetimde erkekler var dikkat ederseniz. Ondan dolayıdır yani erkekler daha iyi beceriyor. ... hastane yönetiminde de mesela süpervizörlerin çoğu şeydir yani erkektir ... Yani artık erkekler daha mı baskıcı oluyor, yani iş yaptırmak konusunda daha mı baskıcı oluyorlar şeylere, bayanlara göre yani .... Hani ben kendim şu anda benim sorumlumun erkek olmasını isterdim." (G.12)

"Belki erkeklerin şeyi daha iyidir yani, yönetimi bazen bayan hani diyor ya savcı bayan olamaz, hâkim bayan olamaz. Çünkü anne duygusu vardır, acır. Ama erkek hemşire onu yapmaz. Elini masaya vurur, böyle olacak der" (G.16)

Örneklemdeki hemşirelerin yöneticilikle ilgili anlatılarında mevcut bir eşitsizlik düşünümsel olarak meşrulaştırılmakta ve etnometodolojik anlamda bir kural haline getirilmektedir. Garfinkel (1967) toplumsal yaşamın özünde düşünümsel olduğunu savunur, çünkü toplumun üyeleri sürekli olarak belirli etkinliklere ve durumlara, bunların altında yatan kalıplar açısından bakarlar ve daha sonra da bu kalıpların bu etkinliklerde ve durumlarda görülen belirli ifadelerine dayanarak bu kalıpların varlığını onaylarlar. Diğer bir deyişle insanlar bir durumu gözlemlediklerinde, durumu kendi inançlarını sürdürecek şekilde yorumlar, böylece kendilerinden bağımsız bir toplumsal gerçekliğin var olduğu sonucuna varır ve kendi inançlarını da pekiştirmiş olurlar. Toplumda kuralların düşünümsel şekilde inşa edilmesi, bu çalışmada hemşirelerin toplumsal cinsiyet eşitsizliklerini meşrulaştırma biçiminde de görülmektedir. 
Toplumda üst düzey yönetici pozisyonlarında kadınların erkeklerden daha az temsil edilmesi, toplumsal cinsiyete dayalı eşitsizliklerin sonucudur. Ancak örneklemdekilerin önemli bir kısmı bu durumu sonuç olarak görmemekte, düşünümsel bir şekilde kural oluşturarak neden ve sonuç arasında döngüsel bir ilişki kurmakta ve toplumsal cinsiyet eşitsizliklerini kural olarak algılamaktadırlar. Diğer bir deyişle siyaset ve din alanlarında lider ya da yönetici pozisyonundaki kadınların azlığını, erkeklerin daha iyi yöneticiler olmasının kendiliğinden bir sonucu gibi kurgulamakta, bu durumu bir kural gibi görmektedirler. Bu nedenle, aşağıdaki alıntılarda da görülebileceği gibi toplum genelinde gücün eşitsiz dağıllımı, erkek hemşireler tarafindan meslek içinde gücün eşitsiz dağılımını meşrulaştıracak bir avantaj olarak kullanılmaktadır:

\begin{abstract}
"Yöneticilikte sadece hemşirelik alanında bence bayanlar daha önde. Diğer branşlara baktığımızda mesela, Cumhuriyet'ten beri baktığımızda, cumhurbaşkanlarımız, başbakanlarımız sayıca bayă̆ bir üstün ki bu her kademede böyle, sadece hemşirelikte bence böyle, zamanla bu da dönecektir diye düşünüyorum. Erkek daha fazla olacaktır diye düşünüyorum ben.” (G.13)

“Diyelim ki 550 milletvekili varsa, bunun nerdeyse 500’ü erkek, yani erkeklerin yönetici olarak bir otoritesi her zaman daha fazladır. Yani kadın-erkek hiç bir zaman ayrımını yapmam, yapanı da sevmem hani, fakat bu bir gerçek olarak görüyorum yani. Erkekler biraz daha otoriter hani o konuda." (G.19)

"Yöneticiler erkek olursa hemşireliğin statüsü değişir saygınlık bakımından. Çünkü geçmişten gelen bir şey, biz ne kadar söylersek söyleyelim, erkek ve bayan eşit değildir. Ne kadar da ben maço değilim, ben sosyalim, ben çok çağdaş bir erkeğim diyen bir insan algısında da bu vardır ki benim algımda da var. Lider her zaman erkektir. Geçmişten beri bu böyle olmuştur. Hani en büyük liderlerden bahsedersek kim vardır? Hz. Peygamber efendimiz vardir, Hz. Isa, Hz. Musa, Hz. Davut vardır. Bayan peygamber duydunuz mu siz? Duymadınız. Ben Hz. Ayşe, Zehra görmedim. ... Almanya'nın başbakanı var bayan. Bir de bizde Tansu Çiller vardl. Başka çok iyi bir yere gelen bayan yok. Genelde erkekler lider konumunda olduğu için ister istemez biraz Allah vergisi kudret güç olduğundan dolayı saygınlık ister istemez. Saygınlı mı dersiniz, korku mu dersiniz, üstünlük mü, ki bu doğuda daha fazla vardır.” (G.8)
\end{abstract}

Bu bulgular, erkeklerin kendileri istemese bile daha iyi pozisyonlara nas1 eriştiklerini göstermektedir. Kadın yoğun mesleklerde çalışan erkeklerin, kendileri talep etmeseler bile toplumsal cinsiyet normlarına aykırı davranmak istemeyen üstleri ve meslektaşları tarafından yönetici pozisyonlarına getirildikleri (Taylor, 2010) bilinmekte ve bu durum "erişim ve muamele ayrımcılığı" (Mclean ve Kalin, 1994) olarak adlandırılmaktadır. Bu ayrımcılık, 
Bourdieu'nun (2014: 119) vurguladığı gibi, cinsiyete dayalı işbölümünün bir kadının bir erkek üzerinde otorite uygulayamayacağ 1 ilkesinden kaynaklanmakta ve uygulamada "cam asansör"e (Williams, 1992) dönüşmektedir.

Örneklemdeki kadın hemşirelerin çoğu erkeklerin meslekteki avantajlarını meşru kılacak ifadeler kullanmış ve cam tavanı içselleştirdiklerinin işaretlerini vermişlerdir:

"[Erkeklerin yönetici olması] uygun, bence uygun, hatta daha iyi olur. $\mathrm{Ne}$ bileyim, kadınlarımı bu konuda hassas. Yani bugüne kadar gördüğ̈̈m bütün erkek yöneticilerden memnun kaldım ben. Benim bugüne kadarki yöneticilerim hep doktor olduğu için yani hep doktorlar yönetici, başhekimlerimizle birlikte çalıştığımız için bayanlar hep bir sıkıntı yaşamıştır yani gözlemlediğim kadarıyla. Yani erkek daha nasıl diyeyim, ince detaylara girmiyor. Ama kadinlar biraz daha hassas oluyor, daha doğrusu daha kaprisli oluyor, maalesef ki öyle." (G.25)

"Toplumda kadın erkek eşitsizliği bence var, kayırma da olur tabii. Yöneticilikte bayanlar getirilirken daha dikkatli olunuyor. Erkek daha öncelikli oluyor. Ama yani önceliğini zaten biliyorsunuz, eee banka müdürleri erkek, ondan sonra ne bileyim PTT'ye gidin, PTT'nin müdürü erkek. Gittiğiniz her tarafta zaten müdürler hep erkek oluyor. Bayanların daha duygusal olmasindan mi, kendi aralarinda birini tutmast, taraf tutması kolay ondan mi artık, ya da belki biz talep etmiyoruz, zaten ağır bir meslek, ekstradan iş yükü olacak diye istemiyor olabiliriz ... bence yönetici erkek olabilir. Çalışanların sevgi ve saygısı içinde bu şimdilik böyle olur, yillar sonra belki değişir." (G.37)

"Mesela acil yoğun, karışık, hasta yakınlarının geldiği bir bölüm, çok karışı işte, yaralanma vakası geliyor. Her türlü vaka geliyor. Bayan hemşire biraz pasif kalyyor diyebiliriz. Her şey geliyor, herkes geliyor diyebiliriz. Erkek bu durumda daha aktif kaliyor.” (G.34)

Yukarıdaki alıntılarda görülebileceği gibi kadın hemşireler de erkek meslektaşları gibi eril bir dil kullanmaktadır. Kadınlara yönelik önyargılar ve erkekleri kadınlardan üstün gören ataerkil ideoloji kadınların ifadelerinde yeniden üretilmektedir. Kadın hemşirelerin, erkek ve kadın kategorilerine zıt anlamlar yükleyerek erkeklerle aynı söylemi paylaşmaları, sembolik iktidarı ve eril tahakkümü kabul ettiklerini göstermektedir. Bourdieu'ya (2014: 50) göre hükmedilenler, tahakküm ilişkilerine hükmedenlerin bakış açısıyla oluşturulmuş kategorilerle baktıkları için bu kategorileri doğalmış gibi algılarlar ve bu durum onları kendi kendini değersizleştirmeye, hatta aşağılamaya kadar götürebilir. Örneklemdeki kadın hemşirelerin ifadeleri, Bourdieu'nun (2014: 17) vurguladığ 1 bir riskin, "eril tahakkümü düşünürken kendileri de tahakküm 
ürünü olan düşünme biçimlerine başvurma" riskinin örnekleri olarak görülebilir. Örneğin, aşağıdaki alıntılarda görüldüğü gibi, kadın hemşireler, duygusallığ 1 kadınla ilişkilendiren ve çalışma yaşamında olumsuz bir özellik olarak gösteren ataerkil ideolojiyi yeniden üretirken kendi kendilerini değersizleştiren bir dil kullanmakta ve cinsiyete dayalı ev içi işbölümünün çalışma yaşamında yarattı̆̆ı sorunları kadınların olumsuz özellikleri gibi yansitmaktadirlar:

“... kadınların adet dönemi duygusalliklart oluyor ya, bir iki hafta öyle geçiyor, bir dişi ăgrtyor, bir midesi ağrıyor, ya da ev sorunların çok yansittyorlar. $O$ anlamda çok da şey olmamall, kadın olmamal yani ...erkek daha güçlü olduğu için" (G.41)

"Yöneticilikte erkeklerin yapması daha iyi olur. Mesela hani benim bir arkadaşımın çocuğu hastalandı̆̆ındaki benim yaklaşımımla, bir erkek arkadaşımın yaklaşımının aynı olmayacağını düşünüyorum. Hani onlar biraz daha iş merkezli çalışır diye düşünüyorum. ” (G.27)

Sembolik şiddet, kadınları otorite konumlarından uzak tutmak, hak taleplerine kapris muamelesi yapmak ve yumuşak bir sözle geçiştirmek, saçlarına ya da bedeninin başka yerlerine dikkat çekerek "kadınlıklarını" hatırlatmak şeklinde görülebilir ve kadınların ikincil konumlarının sürdürülmesini sağlar (Bourdieu, 2014: 79). Hemşirelerin anlatılarında kadınlık tahakküm kuranın gözünden inşa edilmekte, duygusallık, ev işleri, çocuk bakımı, menstrüasyon, hamilelik ve doğumun merkezde olduğu bir eksende konumlandırılmakta ve kadınlık konumunun "zayıflığı" tekrar tekrar hatırlatılmaktadır. Erkek hemşireler bu yolla kadınları sembolik şiddete maruz bırakmakta, kadın hemşireler de maruz kaldıkları sembolik şiddeti ataerkil bir düşünümsellik yoluyla içselleştirmektedirler. İnsanların biyolojik farklılıklarının toplumsal cinsiyet eşitsizliklerini zorunlu k1ldığ düşüncesi Türkiye'de toplumun farklı kesimlerinden destek gören, erkek egemenliğini destekleyen bir düşüncedir (Sancar, 2013). Bu durum Türkiye'de hemşirelik mesleğinde kadın ve erkeklerin prestij ve ücret açısından farklılık gösteren alanlarda yoğunlaştığı cinsiyete dayalı yeni bir işbölümünün ortaya çıkmasında (Dikmen Özarslan, 2015) en önemli etkendir. Erkeklerin "yaratılış" itibariyle çeşitli açılardan üstün görülmesi, hangi meslek söz konusu olursa olsun üstün oldukları varsayılan alanlarda erkeklere yönelik pozitif ayrımcılıkla sonuçlanacaktır ve hemşirelik de bu durumun istisnası değildir.

\subsection{Mesleki Azınlık Olmanın Yarattığı İzolasyon}

Meslekte sayıca azınlık olarak çalışmanın erkek hemşireler üzerindeki etkilerini inceleyen bazı çalışmalar erkek hemşirelerin sosyal izolasyona maruz 
kaldıklarını (Smith, 2006), bazı diğer çalışmalar ise bu tip bir izolasyonun söz konusu olmadığını, erkek hemşirelerin işyerlerinde erkek doktorları da içeren destek ağlarına sahip olduklarını (Andrews vd., 2012) göstermektedir. Bu çalışmanın örneklemindeki erkek hemşirelerin yaklaşık yarısının erkek doktorları da içerecek şekilde erkek iş arkadaşlarından oluşan sosyal ağları vardır, ancak genel olarak çalışma sırasında cinsiyete bağlı bir izolasyon ya da gruplaşma olduğuna dair bir bulgu elde edilmemiştir. Kadın ve erkek hemşireler arasında gruplaşmalar olsa da bu gruplaşmalar kadın ve erkeklerin birbirinden tecrit edildiği ve Sancar'ın (2013: 306) "tek cinsli cemaatleşme" olarak adlandırdığı geleneksel toplumsal ilişkilerin bir yansımasıdır. Aşağıdaki alıntılarda görülebileceği gibi, gruplaşmalar meslek içi izolasyondan değil, gündelik yaşamdaki etkinliklerin homososyal yapısından kaynaklanmaktadır:

“...biz halı saha maçlarına da gittik. Türkü bar tarzı yerlere de gittik. Sinemaya falan gittik yani erkek hemşireler, erkek personel yani kadın yok. Gruplaşma ister istemez o her ortamda oluyor. Kız kıza çekilelim, dedikodu yapalım. Erkek erkeğe gezelim, şurada çay sigara yapalım falan.” (G.4)

"Erkek arkadaşlarla çıkarız da. ... Bizim bayanlarla [kadın hemşirelerle] hani şu şekilde dışarda yemek şey olsun bu bizim kültürde uzak olduğu için ... bizim burada hele bir de o kızın annesi, babası, kardeşi, abisi görse zaten yandin ya." (G.20)

"Çok nadir, mesela pratisyen hekimle ekip arkadaşımızın çocuğu olmuştu. Oraya gideriz. Ama oraya da gitsek hani bir bayan hemşiremiz yok yani çünkü kesinlikle adı çıkar yani Urfa gibi bir yerde, özellikle de bizim hastanede." (G.14)

Örneklemde yer alan erkek hemşirelerin büyük kısmı işyerinde cinsiyete dayalı gruplaşmalar olmadığını ve kadın hemşireler tarafından dışlanmadıklarını belirttikleri için literatürde belirtildiği şekliyle bir sosyal izolasyonun gözlenmediği söylenebilir. Bununla birlikte aşağıdaki alıntıda bir örneği görüldüğü gibi bazı erkek hemşireler için meslekteki kadın yoğunluğu günlük yaşama yansımakta ve meslek içinde azınlık olduklarına dair algıyı pekiştirmektedir:

"Şimdi şöyle bir şey var şimdi azınlıkta hissediyoruz kendimizi. Şimdi kırk üç kişinin içinde dört beş kişiyiz biz erkek olarak. Onların hemşire odasında oturuyoruz yani biz de hemşireyiz ayr bir şey de, aynı yerde yiyip içiyoruz öyle söyleyeyim. Ama ne biliyim biraz daha erkek sayıs fazla olsa daha iyi olur diye düşünüyorum. Şey çünkü bir şekilde sabahtan akşama kadar içerdesiniz. ... Ne bileyim daha fazla erkek olsaydı muhabbet etmek için, bir iki maç muhabbeti yapayım desen kimse yok. ... benim vakadan çıkınca bir oturup dinlenme odam erkek olarak 
yok çünkü bayan hemşire odası var. Erkek hemşire odası olarak ben de ayağımı uzatmak istiyorum ama bayan arkadaşlarım olduğu için bir yere kadar oturup kalkabiliyorum. Onlar da benden rahatsiz oluyor ben de onlardan rahatsız oluyorum. Bir yere kadar. ... Zaten şey olarak erkekler hemşire olarak düşünülmüyor zaten öyle bir sistem şu andaki sistem. Biz bu işi yapıyoruz ama önemli olan bayanlar şu an. Ayrımcllk olarak saylsal olarak bayanların sayısı çok olduğu için şu anda önemli olan bayanların istekleri. Bizim isteklerimiz hiçbir zaman göz önünde bulundurulmamıştır yani." (G.2)

\subsection{Kadın Hastalara Dokunma Konusunda Kaygılar}

Çeşitli çalışmalar erkek hemşirelerin kadın hastaların bedenlerine dokunmalarını gerektiren işleri zor bulduklarını, temaslarının yanlış anlaşılmasından ve suçlanmaktan endişelendiklerini (Evans, 2002; Fisher, 2009) göstermektedir. Toplumsal cinsiyet normları kadın ve erkek hemşirelerin kullanabileceği iletişim araçlarını farklı şekilde sınırlandırmaktadır. Örneğin dokunmak, hastalarla kadın hemşireler arasında rahatlatıcı bir etkileşim aracı olarak normalleştirilmiştir, ama erkek hemşireler hastalara dokunmadan önce dokunuşlarının cinsel açıdan uygunsuz olarak yorumlanmaması için yanlarında bir meslektaş veya refakatçi bulundurmakta veya dokunma gerektiren görevleri kadın hemşirelere transfer etmektedirler (Evans, 2002; Keogh ve Gleeson, 2006).

Örneklemdeki hemşirelerin büyük kısmı kadın hastalara dokunma ile ilgili tedirginliklerin erkek hemşire olma deneyimi açısından son derece önemli olduğunu düşünmekte, ancak kadın hemşirelerin erkek hastaya dokunması ile ilgili olarak da benzer endişelere sahip olduklarını vurgulamaktadırlar. Bununla birlikte ameliyathane ve yoğun bakım gibi hastaların bilinçlerinin kapalı olduğu alanlarda erkek hemşirelerin dokunmasıyla ilgili endişelerin söz konusu olmadığ 1 gözlenmiştir. Hastaların bilinçli olduğu ve fiziksel temas gerektiren diğer alanlarda ise hemşireler çoğunlukla kendiliğinden ve geçici süreli bir cinsiyete dayalı işbölümü yaptıklarını, özellikle mahrem olduğu düşünülen işlerde kadın hastalara kadın hemşirelerin, erkek hastalara erkek hemşirelerin bakım verdiğini belirtmişlerdir:

"Kız olduğu zaman zaten hani çok bir bakım yapmıyorsun. Elektrot takarken tişörtünü kaldırıp elini sağ göğsünün altına koyman lazım. Ya da EKG çekerken göğsünü elinin tersiyle itmen lazım. ... Tepki gösteren olmaması için bayan hemşire arkadaşlara yönlendiriyoruz. Buraya sen gir, erkek olursa buraya ben gireyim.” (G.8)

“Burası bayă̆ı tutucu olduğu için yani böyle Türkiye'de çok az yerlerden olduğu için burası şöyle şeyler olabiliyor mesela, bizim serviste bir 
zaman erkek hasta çoktu, EKG çekmek gerekiyordu mesela bayan arkadaşlarımız rica edebiliyor bizden. Onu çeker misin diye. Bu batıda sikınt olmayabiliyor. Olmuyor da zaten. Ama burada hastalar istemiyor ya da bizim arkadaşlarımız istemiyor, erkeğin vücudunu görmek istemiyor. Ya da aynı şekilde biz bayanın vücudunu görmek istemiyoruz, sen çeker misin diye aramızda çok sıkıntı olmuyor yani.” (G.13)

“... yanlış anlamayın ama burada şey sıkıntılıdır biraz. Ha mesela diyelim, atıyorum cerrahi servisinde çalışlyorum mesela, bayan hemşire de çalışıyor, erkek hemşire de çalışıyor. Yav gün geliyor ki, adam diyor ki yav, sonda takılacak hastaya, diyelim işte 402'deki hasta kimin, Ayşe'nin hastası, sonda takılacak. Normal şartlar altında Ayşe'nin gidip o sondayı takması lazım yani erkek hasta da olsa. Sonuçta bizim işimiz mahremiyetçi, önemli ama yani sağllk için yapman lazım onu. Ama mesela n'oluyo, diyo ki hastanın sondasın takabilir misin, ben gidiyorum taklyorum. Hem hasta bana karşl rahat ediyor, hem ben ona göre rahat ediyorum. Aynı şekilde bayan hastanın sondası oluyor. Ayşe hastanın sondası var gidip takabilir misin, yani bu şekilde ben daha iyi olacağını düşünüyorum yani. Onun için böyle, ama Batı tarafını çok bilmiyorum. Benim mezun olan arkadaşlarım var, mesela Aytekin var Eskişehir'de, Bekir var Antalya'da. Oralarda böyle bi sıkıntı yok diyorlar hani, sadece zaten sağlıkçısın, işini yapmak zorundasın, ki yapman lazım bayan da olsa erkek de olsa orda. Ama işte bu taraf biraz sıkıntıll, yani gerçekten Urfa sıkıntılı, onun için [erkeklerin hemşirelik yapmaya başlaması] daha iyi oldu diye düşünüyorum ben." (G.12)

Yukarıdaki son iki alıntıda bahsedilen doğu ve batı arasındaki fark, Urfa'da çalışan erkek hemşirelerle yapılan bütün mülakatlarda vurgulanmıştır. Aşağıdaki alıntılardan da görülebileceği gibi bu farklılık, kadın hastalara dokunma konusunda olduğu kadar kadın hemşirelerin çalışma alanlarının sınırlılığıyla ve kadın ve erkek hemşireler arasındaki mesleki etkileşimle de ilgilidir:

"Mesela şeydir Urfa'da, özellikle mesela yoğun bakımda biz bir yere giderken, bi bayanı götüremiyoruz. Bayan Urfa'da biliyorsunuz, ya çekinir ya da birinden çekinir, ya ailesinden çekinir. Yani muhakkak bir şey vardır. Onun için pek, o yönden anlayış gösterdiğimiz için, ama İstanbul'da olsa, Mersin'de olsa götürürsün, arkadaşlarını götürürsün, çocuğunu götürürsün. Belki oralar buralardan daha rahattır, daha rahat davranırlar. Ama burda öyle bir şansımız yok.” (G.16)

... "bizim burda özelikle Urfa yöresinde hemen hemen her işi bayan yapar. Evdeki mesela köylü bi bayan düşünelim. Mesela tezeği şey yapar, gider davarı getirir. ... erkeğin yaptığ bir şey yok ki. Gider gelir yani. Başka da bir şey yok yani. Ama hani nasıl diyelim. Şehirde de bi fark yok 
yani yemek olsun şey olsun her şeyi onlar [kadınlar] yapar yani. Hani ben hastanede bir şey istesem, yani mesela orda bir bardak varsa isterim yani bayan [hemşire] orda olsa. Gelir onu alır mesela getirir. Bu şekilde bir şey var. Hani yanlış da olsa böyle bir şeyler var. Ama hani batı tarafina gittiğimizde stajda gördüm ben bunu, tamamıyla her şey değişiyor tabi ki. Böyle diyemiyorsun şunu uzatır misın diye, tam tersi onlar sana o şekilde yapıyorlar. Onlar [kadınlar] burada otursa dahi biz orda olsak hani istediğinde biz onu alıp vermek zorundaymışız gibisinden.” (G.20)

"Ya mesela şöyle sorsan derler ki, sağllk hiçbir şekilde belli alanlarla sinırlandırlmaz derler. Ama ben kesinlikle hani hem katılip hem katılmama durumum var. Mesela bi çocuk servisinde pekâlâ da bi erkek hemşire çalışabilir ki çalışıyor da zaten. Ama bu konu mesela bi kadın doğum servisine bi kadın doğum servisinde kalan hani bi erkek hemşire kolay kolay çalışamaz. Hani belki de toplumumuzdan dolayl, gördüğümüz nedenlerden dolayı çalışamaz diyorum. Bana göre yapmamaları gerekir. Gerekir derken, hani dediğim gibi çevremizde gördüğ̈̈müz etik durumlardan dolayı hani ne bileyim. Ama belki de ilerde değişir. Ama değişse bile benim kanaatim bu." (G.11)

Urfa'da çalışan erkek hemşireler içinde hiçbiri, Eskişehir'de çalışanlar içinde de kırsal alanda doğanlar özellikle kadın doğum servisinde çalışmak istememektedir. $\mathrm{Bu}$ konuyla ilgili en önemli gözlemlerden biri, bu tercihin nedeninin ilk anda görünenden farklı olmasıdır. Örneğin, kadın doğum servisinde staj yapmış olan 19 numaralı görüşmeci, görüşmenin ortalarında kendisine kadın doğum servisinde çalışmasının teklif edildiğini, ancak "o serviste çalışan hemşirelerin hepsi bayan" olduğu için bu teklifi reddettiğini söylemiştir. Ama görüşmenin ilerleyen saatlerinde, aşağıdaki alıntılarda görülebileceği gibi, doğumu "çirkin" ve "kirli" bir iş olarak gördüğü ve staj yaparken de doğumhanedeki işten uzak kalmaya çalıştığ gözlenmiştir. Aşağıdaki alıntılarda görülebileceği gibi bu tip örneklerde kadın doğum hemşiresi olarak çalışmak, hastanın istekleri ya da dokunuşun fazla mahrem bulunabileceği endişesi nedeniyle reddedilmemektedir, asıl neden doğum halindeki kadını görmenin hegemonik erkeklik içinde kurgulandığ şekliyle cinsel olarak arzulanan kadın bedeni imajını zedelemesidir:

"Benim sorunum vardl, o staj yaptı̆̆ım yerde ... ben gitmek istemiyordum doğum yapan bir bayanın yanına. Zorladı beni, herhalde hocam da söylemiş gitsin, görsün diye. Ben tamam gidecem diyordum, gitmiyordum, dolanıyordum tekrar geliyordum. Sonunda gitmeyeceğimi anlayınca kendi eliyle götürdü. Oraya koydu, sonra bir bayanın doğum yaptı̆̆ anı gördüm. O anda gerçekten ben de çok tiksindim yani bayanlardan"(G.19) 


\begin{abstract}
"Benim kendi görüşüm, çallşmaması lazım. Ya ben kendim de mesela yanlış anlaşılmasın yani doğuma da girdim, doğum da yaptırttım hani mesela. Gördüm ama bence yani olmaması lazım daha doğrusu. ... Bilimsel bir iş yapıyoz da, ya sıkıntılı bir yer. ... Yani mesela, orda bayanlara karşı aslında şey oluyor erkekte. Bir tiksinme olayı oluyor. Genelde, sadece bende değil, bu bütün erkeklerde olan bişi. Hepimiz, mesela biz altmış beş kişiydik sınıfta, otuz iki, otuz üç erkek falan vardı. Hepimiz de gördük mesela, doğum, kadın şeye girdik, doğum yaptırdık mesela. Hani genelde ilk söyledikleri şey, tiksindik yani. Mesela şeyden, ilişkiden, seksten diyeyim hadi. Açık konuşmak gerekirse, ondan tiksindik yani, sıkıntılı. Bence bayanın yapması daha iyidir yani." (G.12)
\end{abstract}

Benzer şekilde stajını kadın doğum servisinde staj yapmış olan bir başka görüşmeci de, önce "iş yükü fazla" olduğu için kadın doğum servisinde çalışmak istemediğini söylemiş, ancak görüşmenin sonlarına doğru, kadın doğum servisinde çalışmakla ilgili düşüncelerinin temelinde yatan staj anılarından birini anlatmıştır. Aşağıdaki alıntıda görüldüğü gibi kullanılan eril dil aracılığıyla kadın bedeni pis ve kirli bir beden olarak inşa edilmekte ve bu durum erkeklerin üstünlüğünün bir işareti olarak yorumlanmaktadır:

“Kadınlar bana hep böyle şey gelmiştir .. kibar bayan, nazik. ... bayanlar daha dikkatli, tiziz, temizdir. O halde [staj yaparken doğum sırasında] görünce dünyam ylkıldl. Öyle bayanlar gördüm bi giyinmiş bi makyaj var, ăgzının suyu akar. Geliyo oraya doğumhaneye ya da muayeneye yani normal, bi kir bi pislik. Noluyo lan dedim. Altında yatan şeyi ben yeni mi farkediyorum diyosun. Aslında kadınlar kafamda büyüttügüm kadar da değilmiş diyorum kendi kendime. Ĕ̆er o dönemde kız arkadaşım olsaydı ayrllırdım. İğrendim. Eve girdim, kız kardeşimin yediği tabaktan yemiyorum. Ve kendimi üstün görmeye başladım. ... Savaş abi hal mesele budur dedim. Sonuçta o da erkek orda çalışıyor. Gel senle sigara içelim dedi. Sigara içtik. İlk ay böyle olur. Sonra yine aşık olursun yine seversin dedi. Sadece bilmediğin şeyi ögrendin sen dedi. Evet bunu kabul et dedi. Bayanlar erkeklere göre daha pistir dedi. Erkekler yaradılış olarak temiz varlıklardır, bir şeyleri yoktur dedi. Kanamaları, doğumları yoktur dedi. Onların her ay kanamalarl var düşünsene dedi ve her ay o kokuyu çekiyorlar sen biliyo musun dedi. Üç gün, dört gün, beş gün sancıları bitmez dedi. Adam hemşire o kadar kızın içinde." (G.8)

Kadın doğum servisinde çalışmak istemeyen bir diğer görüşmeci de görüşmenin başında "benim çalışmamamın tek sebebi var orda, o da hasta yakınlarının erkek hemşirelere farklı gözle bakmaları" derken, ilerleyen bölümlerde kadın doğum bölümünün "bayağı" ve "önemsiz" olduğunu düşündüğünü belirtmektedir: 
"Ne yazık ki kadın doğum biraz daha geride kalmış bi servis. Şöyle diyelim bi de Türkiye kendini kadın doğumda ilerletmemiş mesela, yüz nakli yapılabiliyor ama bu kadın doğum özellikle bayă̆ı. ... Kadın doğum uzmanlarının birçoğu baktı̆̆ımız zaman erkek zaten. Bilmiyorum siz karşılaştınız mı ama birçoğu erkek. ... Yani onlar madem bu işi yapabiliyorlarsa biz de yapabiliriz yani. Bence yapılabilir ama biraz da biz de şey durmuyor, hani daha rahat bölümler varken neden kadın doğum olsun ki o var. Mesela beyin cerrahinde gidip yapmak varken ya da yani daha güzel, daha önemli bir yer varken niye kadın doğumda çalışayım?" (G.20)

Diğer taraftan Urfa'da çalışan bazı erkek hemşireler, kendileri çalışmak istemeseler de genel olarak erkek hemşirelerin kadın doğum servislerinde çalışması gerektiğini düşünmekte, yine de bu durumun Urfa için geçerli olmadığını vurgulamaktadırlar:

“Türkiye'nin daha batısında yaşasak belki o bi sıkıntı olmayabilir ama özellikle bu doğu kesimlerinde, bizim yaşadı̆̆ımız Maraş’ta, Urfa taraflarında insanlar biraz daha dar görüşlü açıkçası böyle yani. Yani değil doğuma girmek, insanlar evde tek kişi kaldı ̆̆ında, bayan kaldı̆̆ında evde tek yani sokaktan geçerken böyle bakabiliyor sana. ... Yani bi bayanın arabaya binmesi bile abes karşılanabilir buralarda ama batıda bu sıkıntı olmuyor. O yüzden burda olmaz öyle bir şey ... Özellikle Şanlıurfa'da olmaz. Biz Kütahya'da staj yaparken çalışıllyordu. Doğuma giriyorduk biz. Sonra buraya geldik, burası öyle değil yani. Kültürel farklılıklar var, ama bence olması lazım.”(G.13)

"Batı kısmını bilmem de, bizim doğuda bayan için mesela fazla mahremiyet. Ha bir İstanbul'da bir Eskişehir'de yapsin mesela sıkıntı olmaz yani. Hatta erkeklerin el becerisi biraz daha iyi olur diye düşünüyorum yani. Tabi bizim mesela kadın-doğum uzmanlarının bayanlardansa erkek doktorlar daha iyi. Ama doğuda ben yapmam yani, en azından kendim adına." (G.17)

"Batı tarafında staj yaptığımız için pek bu sıkıntılar olmuyordu. Erkek hemşire bile olsa bayana tedavi verdiğinde hiç bi sakınca falan görmüyorlardı yani. ... . Benim yaşadı̆̆ım, stajımı Bolu'da yaptı̆̆ım için, Bolu'daki insanlar bu konuda biraz şey, yani iyi niyetliler yani erkek bayan olsa hiç bi ayrım gözetmiyorlar yani. O konuda hasta yakınları hiç bi sıkıntı çıkarmamışlardı. Bayan hastalara tedavi verdiğimde, hani mahremiyetle ilgili tedavi verdiğimde bi sıkıntı yapmıyorlard illa ki biz bayan isteriz diye. Ama doğuya doğru gelince biraz daha erkekler için sıkıntı oluyor. Bayanlar bayan hemşire genelde istiyor normal şeyde serviste. Ya da hasta yakınları erkek hemşirenin kendi hastalarına bakım 
vermesini istemiyor. Kadın doğuma gelene kadar yani her şeyde sıkıntılar var" (G.18)

Dokunma konusunda en öne çıkan kaygılardan biri hastaların olası şikayetleri karşısında erkek hemşirelerin durumudur. Hemşireler bu gibi durumların önüne geçebilmek için erkek hemşirelerin yanlarında hastanın refakatçilerini veya yakınlarını bulundurmasını stratejik olarak önemli görmektedirler:

“... hasta istemese bile varsa yakını ben allyorum yani. ... Çünkü bir bayan karşındaki ne olursa olsun. Çünkü suçlansa yani nasıl diyeyim ne olursa olsun haklı durumda oluyor bayan çünkü hani tanımadığı yabancı birisin.” (G.14)

"Kapalı bir ortamdaysa ikimiz varsak erkek hasta için pek problem olacağını zannetmiyorum ama karşındaki bayan hastaysa ve kapalı ortamda ikiniz varsanı sıkınt oluyor. Şahit yok ve herhangi bir şeyle suçlanabilirsin.” (G.9)

“...bayan hemşirelerde çok fazla olan bir şey değil onu hiç kale almiyorlar ama erkek söz konusu olduğunda bayanda bir hani beni taciz edecek oramı açacak mı şeyi oluyor kesinlikle. Ama burada bayan hastalar bence şey içten pazarlıkl, yani olmasa bile olmuş gibi gösterebilir ve buna da kimse hayır olmadı deme şansı yok çünkü kadın bana böyle yaptı tacizde bulundu diyorsa kadın haklı görünüyor.” (G.24)

Örneklemdeki erkek hemşirelerin kadın hastalara dokunma konusundaki kaygıları ve bu sorunla baş etme stratejileri literatürdeki çalışmalarla (Evans, 2002; Fisher, 2009; Keogh ve Gleeson, 2006) uyuşmaktadır. Dokunma konusundaki bu kaygılar meslekle ilgili başka düşüncelerde de görülmektedir, örneğin örneklemdeki hemşirelerin yaklaşık üçte ikisi erkek hemşirelerin kadın doğum bölümlerinde çalışmasının "uygun olmayacağını" düşünmektedir. Dolayısıyla mevcut bir sorunla ilgi geçici işbölümü kısa vadeli bir çözüm olabilir, ancak mesleki alanda formel bir işbölümüne dönüşürse meslek açısından çeşitli sorunlar yaratma potansiyeli taşımaktadır. Hem sağlık hizmetlerinde evrensellik ilkesini, hem hastaların ve hemşirelerin hak ve taleplerini hem de taciz konusunu içeren dokunma teması şüphesiz erkek hemşirelik konusunda daha derinlikli araştırmaları gerektirmektedir.

\subsection{Cinsel Kimliğin Sorgulanması}

Hemşirelik mesleğinin geleneksel olarak kadınlara atfedilen normları içermesi erkek hemşirelerin erkeklik algıları ve rolleri ile meslek rolleri arasında bir gerilime neden olmaktadır. Çeşitli çalışmalar (Wingfield, 2009; Evans, 2004, 2002; Harding, 2007; Brown, 2009; Battice, 2010) erkek 
hemşirelerin standart hegemonik erkekliğin dışında görüldüklerini, eşcinsel olduklarına dair önyargı ve alaylarla karşılaştıklarını ve homofobik tacizlere maruz kaldıklarını göstermektedir. Hegemonik erkekliğin yarattığı sorun iki yönlüdür, erkek hemşireler bir yandan cinsel açıdan saldırgan potansiyel tacizciler olduklarına dair, diğer yandan kadın işi yapan eşcinseller olduklarına dair önyargılarla karşılaşmaktadırlar. Bu çift yönlü önyargıların erkek hemşirelerin hastalarıyla rahat ve güvenli ilişkiler geliştirmesini engellediği vurgulanmaktadır (Harding, 2007; Lodge vd., 1997).

Örneklemin yarısından fazlası erkek hemşirelerin cinsel kimliklerinin ne hastalar ne de meslektaşları tarafından sorgulanmadığını düşünmektedir. Ancak görüşmecilerin eşcinsellikle ilgili anlatılarının büyük kısmı oldukça kısa ve katıdır, üstelik sıklıkla başka kültürlere ya da mesleklere referans veren homofobik ifadeler içermektedir. Görüşmecilerin herhangi bir meslekle cinsel yönelim arasında bir ilişki kurmadıklarını söylemek zordur, aşağıda bazı örnekleri görülebileceği gibi daha ziyade bir homofobiyi paylaşır görünmekte ve olumsuz değerlendirdikleri bu durumla kültürel aidiyetleri arasına bir sınır çizmeye çalışmaktadırlar:

“Biz Türküz, Türk kültüründen gelmişiz...olmaz” (G.15)

“Böyle bir şeyin olması mümkün değil”” (G.20)

"Söz konusu değil ... Türkiye şartlart için bence geçerli değil” (G.33)

“Kuaförler olabilir mesela ama hemşireler olamaz” (G.40)

"Onu da saklayacaktır öyle bir şey olursa, herhalde söyleyecek değildir" (G.2)

Bunun yanında kadın hemşireler ağırlıkta olmakla birlikte hemşirelerin bir bölümü, sürekli kadınlarla birlikte çalışmanın erkekleri kadınsılaştıracağını düşünmektedir. $\mathrm{Bu}$ düşünce, cinsel yönelimleriyle ilgili alaylarla karşılaşmasalar bile erkek hemşirelerin cinsel yönelimlerine dair örtük önyargılarla karşı karşıya olduklarını göstermektedir. Bazı erkek hemşireler bu durumu aşağıdaki gibi ifade etmektedir:

“...Bayanların arasında ister istemez onlar gibi oluyorsun yani. Konuşma şekli mesela ... bayana karşı konuşma şekli, onların arasında olunca işte arkadaşını söyle kim olduğunu söyleyeyim, ya da arkadaşın gibi yürürsün şey gibi yürürsün gibisinden, o olabiliyor. Genelde o olabiliyor yani." (G.12)

“... ne denir cahillik mi denir, eskilerden gelen gelenek mi denir yani zamanla değişecek yani, erkek hemşireler çoğaldıkça. Ben okuldayken ögretmenden bile duymuştum hani, yirmi dört kişilik sinıfta atıyorum yirmi iki kız iki erkek, erkeğin hal ve hareketleri bile değişir gibisinden 
dediğini ben kulağımla ögretmenden bile duymuştum yani. Bunlar yani bilmiyorum ögretmen bir de, yani okumuş insan." (G.4)

Kadın hemşirelerin erkek hemşirelerin "kadınsı" davranıșlarına dair önyargıları, aşağıdaki alıntılarda görülebileceği gibi hem homososyal kültüre, hem de kadın yoğun mesleklere ilişkin toplumca kabul edilen önyargılarla ilişkilidir:

"Hemşirelik bayan mesleği olduğu için, aynı hosteslikte ya da sekreterlikte olduğu gibi, ya hani böyle bayan mesleği olduğu için işte nasll diyeyim, hani hosteslerde de vardır ya o olay hani oynak olmak." (G.39)

“....servisinde çallşan bir tane hemşire erkek var, çoğumuz kadın. ... Artık hep aynı konuları konuştuğumuz için o konuşmalar sıradanlaşıyor ve işte aynı konuyu o konuşunca şey diyorsunuz demek ki meyli var, demek ki içindeki dürtüyü mü ortaya çıkardı diye düşünüyorum.” (G.22)

“... bir arkadaş vard şimdi [başka hastaneye] gitti. Hani ben bile onu kendimce öyle düşünüyordum ... Çünkü şeydi davranışları çok böyle yumuşamıştı. Hani bir de on tane bayan hemşire varsa bir tane erkek hemşire, hani o da onların arasında böyle kadınlaşmıştı gibi, bir davranış değişikliğine uğramıştı arkadaş. Benim sadece bu bir gözlemim.” (G.24)

"İşte çok fazla bayanla çalıştıkları için, hani bayan kuaförlerine bir şeylik olur ya hani bakım artışı. Kişisel bakımını arttırıp, çok fazla eğilimler olur ya. Çok fazla bayanla çalıştığ için erkeklerde de şöyle bir eğilim oluyor. İşte yemek tarifleri öğrenme, çocuk bakımılla ilgili bilgi sahibi olma, bir de bunu konuşmaya başlama falan gibi. Hani o onu biraz şey yapar, mmm işte biraz hafif meşrep yapar yani. ” (G.39)

Diğer taraftan bazı erkek hemşireler kadınlarla birlikte çalışmanın heteroseksüellik üzerinden hegemonik erkekliği pekiştirdiğini belirtmektedir:

“...Türkiye'de tam tersi diyeyim o konunun, yani normal erkeklerin daha üstün olduğu düşünülüyor toplumca. Mesela benim düz bi lisede okuyan üç tane kız arkadaşım diyor, adam sağlık meslek lisesinde okuyor on tane kız arkadaşı var gibisinden. Anlatabildim mi? Yani sağllk meslek üç tane erkek on sekiz tane kız, o adam olmayacak da biz mi olacaz diyo mesela. Mesela şu durum var. Size şunu söyleyeyim, să̆llk meslek lisesindesiniz ve kız arkadaşınız yoksa dışlanırsınız.” (G.14)

Örneklemdeki erkek hemşireler, kadın hastalara dokunurken cinsel içerikli düşüncelere sahip olmadıklarını özellikle vurgulamaktadırlar. Ancak işini yaparken hegemonik erkeklik normlarına uymuyor olmak, telafi edilmesi gereken bir durum gibi görülmektedir. Her koşulda erkekliklerini ispatlamaya 
zorlanan erkekler, hegemonik erkeklikten mustarip olduklarında bile erkeklik üretmeye (Bourdieu, 2014: 69; Atay, 2012: 18) devam etmektedirler. Örneğin sekiz numaralı görüşmeci, "üniforma üzerimde ya, hiçbir şey hissetmiyorum. Allah gözüne perde mi çekiyor o duygu sana nasil geliyor belli değil" ifadesiyle hastalara dokunurken tamamen bilimsel ve etik kurallara uygun şekilde davrandıklarını anlattıktan sonra, bu "cinsiyetsiz" halin erkeklik kimliğinin tümüne genellenmesini önlemek amacıyla, işten çıktıktan sonra hegemonik erkeklik normlarına geri döndüğünün altını çizmektedir:

“... Hastaneden çıktım otobüse bindim. Önde bir bayan var dekolte giyinmiş, oturmuş, ben ayaktayım. Tam dibinde ayaktayım ve gögüs dekoltesi var. Çok ilginçtir ikide bir gözüm kayıyor. Engel olamıyorum kendime. En son artık yerimi değiştirmek zorunda kaldım. Otobüs kalabalık zaten, kimse beni fark etmiyor. Güldüm kendime. On beş yirmi dakika önce her şey ortada ben bir şey hissetmiyorum. Şu an oradaki durumun yüzde beşi bile yok ben niye bu kadar etkileniyorum dedim kendi kendime." (G.8)

Erkek hemşirelerin anlatılarında normların "üniformayı giydikten sonra" değişebildiği sıklıkla belirtilmekte, çalışırken hemşirelik normlarına uyan bir erkeğin iş dışında hegemonik erkeklik normlarına uymaya devam edebileceği vurgulanmaktadır. $\mathrm{Bu}$ vurgu, toplumda kabul edilen hegemonik erkeklik kurgusu ile kadınlara has kabul edilen şefkat, incelik ve nezaket gibi özellikleri gerektiren bir işi yapıyor olmak arasındaki çelişkinin erkek hemşirelerde yarattığı çifte-bilinçlilikten (Orbe, 1998) kaynaklanmaktadır. Erkek hemşireler yöneticilik pozisyonlarına gelmek söz konusu olduğunda vurguladıkları erkeklik kimliğini, kadın hastalara dokunmak söz konusu olduğunda görünmez kılmaktadır. Diğer bir deyişle erkek hemşireler, toplumsal cinsiyet kalıp yargıları açısından avantaj sağlıyorsa erkeklik kimliğine bağlı kalmakta, ama dezavantaj yaratıyorsa "doğuştan gelen biyolojik ve fiziksel farklılıklara" dayandığını düşündükleri erkeklik kimliğinden bir anda "soyunmakta" ve profesyonellik üzerinden meslek kimliklerine bürünmektedirler:

"Bence o formayl giydikten sonra değişir, hani dışarda sinirli olabilir, asabi olabilir günlük hayatında, eee küfürbaz olabilir. .... Çok pistir ama o formayı giydikten sonra çok düzenli, disiplinli, hastalara karşı merhametli, anlayışlı olması, işini düzenli ve zamanında yapması ... hani iyi bir hemşire örneği çıkar yani” (G.10)

"Ben mesela çıktım normal sivilim. Bana dişardan bi hasta sorsa belki kızarım da, ufak tepki de veririm, ama ben o önlüğ̈̈ giydikten sonra bende çok farkl bir mod oluşuyor. Yeni bi format atıyorum kendime ben, şahsen öyle." (G.11) 


\begin{abstract}
"Ya bunu hani yine ben biraz şeye bağllyacam. Insanın hani dedim ya yetiştirme tarzına bağlıdır. Ben şahsen o formayı giydiğimde yani dışarda olduğum kişi değilim. ... yani, kesinlikle ben o formayı çıkardı̆̆ımda farklı bir insanım, ben o formayı giydiğimde çok farklı bir insanım. Şahsen bende o oluyor yani. Kesinlikle, hiçbir şekilde yani bi kadına EKG çekeyim, göğsünü açayım, bacağını buraya kadar indireyim, kesinlikle yani ben o formayl giydiğimde ben farkl bir duyguya giriyorum." (G.15)
\end{abstract}

Kadın yoğun bir meslekte çalışmak hegemonik erkeklik açısından sorun yaratsa da, işgücü piyasasındaki güvencesiz ve geçici işlerin ve yüksek işsizlik oranlarının baskısını hisseden erkekler için bu sorun, tam zamanlı bir iş bulmanın erkeklik kimliği inşasında yarattığı daha büyük ve olumlu etkinin (Sancar, 2013: 58) gölgesinde kalmaktadır. Hemşirelerin genellikle düşük sosyo ekonomik statülü ailelerden geldikleri dikkate alındığında, istihdamın erkek kimliği açısından öneminin artacağı tahmin edilebilir. Aşağıdaki alıntılarda görülebileceği gibi bazı erkek hemşireler meslekten çok istihdam statüsünü vurgulamakta ve erkeklik kimliğinin göreceği muhtemel zararı istihdamla telafi ettiklerini göstermektedir:

"Hani bize hastanede hemşire hanım diye bağıran da var. Hiç etkilenmem ben şahsen. Sonuçta ben çalışıyorum, şu anda bekârım ama kardeşlerim okuyor. Babama belli bir miktarda maddi yardımda bulunuyorum. Yani onlarl göz önünde tuttuğum zaman hiçbir şey benim gözümde gözükmez yani. ” (G.10)

"Mahalle baskısı işe girmeden önce daha fazla oluyor. ... İşe girmeden önce daha fazla umursuyor. Işse girdikten sonra yani umursamıyor, pek şey olmuyor. ... daha çok akrabalar arasında oluyor ve işte hemşirelik falan filan derken o da bi cevap olarak artık öyle değil, değişti siz öyle düşünüyorsunuz o şekilde konuşma falan. Anlatıyor yani, işe girdikten sonra da yani eline para geçince zaten herkes onu şey yapıyor” (G.19)

\title{
Sonuç
}

$\mathrm{Bu}$ çalışmada erkek hemşirelerin meslek deneyimleri hemşirelerin gözünden betimlenmiş, öne çıkan temalar hemşireliğin erkekler için avantajlı ve dezavantajlı yönleri çerçevesinde değerlendirilmiştir. Erkek hemşirelerin hem avantajları hem de dezavantajları ataerkil ideoloji ve hegemonik erkeklik ekseninde deneyimlenmektedir. Erkekliğin otorite ve güç ile ilişkilendirilmesi, erkek hemşirelerin doktorlara, hastalara ve hasta yakınlarına karşı kadın meslektaşlarından daha otoriter davranmalarına neden olmaktadır. Bu durum hem erkek hem de kadın hemşireler tarafindan doktorlarla hemşireler arasındaki etkileşimi değiştirecek, mesleğin statüsünü yükseltecek ve hemşirelere karş1 
şiddeti engelleyecek bir etken olarak algılanmaktadır. Diğer bir deyişle meslek içinde var olacak bir erkek iktidarının, hemşirelik mesleğinin "kadın mesleği" olmasından kaynaklanan sorunlarını çözmesi umulmaktadır. Ancak erkek hemşirelerin otoriter tavırları kadın hemşireleri de hedef almakta, erkek hemşireler kadın meslektaşlarını "doktorun otoritesi karşısında uysal, önemli kararlar verirken duygusal, aklı ev işlerinde ve çocuklarında kalan, ağır ve karmaşık iş ortamlarına uygun olmayan, fiziksel açıdan zayıf" bir grup olarak tanımlamaktadırlar. Erkek hemşireler kullandıkları eril dille kendilerini kadınlara üstün kılmakta, kendilerinde değerli gördükleri niteliklerin kadınlarda eksik olduğunu vurgulamakta, kadınları hem fiziksel özellikler hem de kişilik özellikleri üzerinden değersizleştirmektedirler. Değerli görülen erkeksi özelliklerin çalışma yaşamında erkeklere avantaj sağlayacağı açıkça görülmektedir. Erkek hemşireler, kendilerinden kadınlardan beklendiği kadar ücretsiz ev içi emeği beklenmediği ve çocuk bakımı sorumluluğunu da kadınlara devrettikleri için mesleğe ayıracak daha fazla zamana sahiptirler ve bu durumun çalışma yaşamında kendilerine avantaj sağladığının farkındadırlar.

Görüşülen kadın hemşirelerin büyük bir kısmı, erkeklerin vasıflarının işgücü piyasasında kadınların vasıflarından daha değerli olduğu yönündeki ataerkil varsayımı yeniden üreterek toplumsal cinsiyet eşitsizliklerinin mesleğe yansımasına katkıda bulunmaktadırlar. Kadın hemşirelerin çoğu, erkek meslektaşları gibi kadını değersizleştiren, ikincil ve sorunlu gösteren eril bir dil kullanmaktadır. Hem erkek hem de kadın hemşirelerin anlatılarında menstrüasyon ya da doğum gibi kadın bedeninin doğal durumları, çalışma yaşamında sorun yaratan süreçler olarak görülmektedir. Kadın bedenini sorunlu beden olarak inşa eden bu eril dil, kadınların duygusallıklarını bir zayıflık olarak, ev işlerini ve çocuk bakımını da kadınların üstlenmek zorunda olduğu görevler olarak göstermektedir. Bu dil aracıllğıyla uygulanan sembolik şiddet, kadınların otorite gerektiren pozisyonlardan dışlanmasına yol açmaktadır. Bu çalışmanın bulguları, Türkiye'de sağlık sektöründe kadınların cam tavanla karşılaştıklarını gösteren çalışmalara (Urhan ve Etiler, 2011; Şimşek-Rathke, 2011) paraleldir. Kadınların çalışma yaşamında yükselmelerini engelleyen cam tavanlar erkek hemşireler için cam asansöre dönüşmekte, kadın hemşireler tarafından içselleştirilmekte, erkek hemşireler tarafından pekiştirilmektedir.

Erkek hemşirelerin meslekteki bu avantajlarına karşılık, hegemonik erkeklik kimliğinden kaynaklanan dezavantajları da vardır. Öncelikle meslekteki aile sembolizmi nedeniyle erkek doktorların sahip olduğu otoriter konum, erkek hemşireler açısından sorunludur. Erkek hemşireler, doktorların baskın tavırlarına karşı kendi erkekliklerini yeniden üretmekte, daha saygın bir pozisyon elde etme çabalarını meslek ekseninde değil, toplumsal cinsiyet ekseninde sürdürmektedirler. Ancak bu çaba, meslekteki aile sembolizminin görünmeyen duvarlarına çarpmaktadır. Doktorluğu ve hemşireliği iki farklı 
meslek olarak görmeyen, doktoru erkeklik ve babalıkla, hemşireyi kadınlık ve annelikle iliş̧ilendiren aile sembolizminin içselleştirilmesi son bulmadıkça ne erkek hemşirelerin ne de kadın hemşirelerin pozisyonlarının iyileşmeyeceği açıktır. Diğer taraftan erkek hemşireler doktorlarla aralarındaki etkileşimi sadece erkek iktidarının gücüne dayanarak iyileştirmeyi başarsalar bile bu durum bütün hemşirelerin çıkarına olmayabilir. Bu tip bir çaba doktorların kaba ya da incitici davranışlarını engellemeyip, sadece erkek hemşirelere karşı daha dikkatli davranmalarına neden olabilir. Kadın hemşireler mesleğin statüsünü yükseltmek ve kendi konumlarını iyileştirmek için erkek iktidarından medet umsalar da erkek doktorlar ve erkek hemşireler arasındaki bir iktidar mücadelesi bütün hemşirelerin değil, sadece erkek hemşirelerin konumunu iyileştirecek şekilde sonuçlanabilir.

Erkek hemşirelerin avantaj ve dezavantajları aynı nedenden, ataerkil ideoloji ve hegemonik erkeklikten kaynaklandığ için iç içe geçmiş durumdadır. Erkek hemşireler bir yandan erkeklerin vasıflarını kadınların vasıflarından daha değerli gören ataerkil ideoloji nedeniyle yöneticilik başta olmak üzere yüksek ücret ve statü sunan işleri kadınlardan daha iyi yapacaklarını düşünmekte, kadınları otorite gerektiren alanlardan dişlamakta ve bu görüşleri kadın meslektaşları tarafindan desteklenmektedir. Diğer yandan ise kendilerine bu avantajları sağlayan ataerkil ideoloji ve hegemonik erkekliğin yol açtı̆̆ dezavantajlar söz konusudur. Kadınsı algılanan bir meslekte ve sürekli kadınlarla çalışmak, açıktan olmasa da dolaylı yollardan erkek hemşirelerin cinsel kimliklerinin sorgulanmasına neden olmaktadır. Bu sorgulamay1 hisseden ya da öngören erkek hemşireler erkeklik kimliklerini pekiştirmek ve meslek normlarına olduğu kadar hegemonik erkeklik normlarına bağlı olduklarını vurgulamak zorunda kalmaktadırlar. Mesleki uygulamaları yerine getirirken hastalara karşı cinsel bir tehdit oluşturmadıklarını, "cinsiyetsiz" bir şekilde çalıştıklarını belirten erkek hemşireler hegemonik erkeklik normlarından tamamen kopmadıklarının, sadece hemşire olarak çalışırken kısa süreliğine uzaklaştıkları bu normları, mesaileri bitip formalarını çıkardıkları andan itibaren yeniden benimsediklerinin altını çizmektedirler. Bu tepki, erkek hemşirelerin meslek normları ile hegemonik erkeklik arasında bir çifte bilinçlilik içine sıkıştıklarını göstermektedir.

Erkek hemşirelerin meslekteki avantajlarının kadın hemşireler açısından dezavantaja dönüşebileceği söylenebilir. Erkeklerin yöneticilik, ücret ve statü açısından elde ettikleri avantajlar kadın hemşirelerin yüksek ücret ve statü sunan alanlardan dışlanmasına neden olabilir. Bunun yanında, erkeklerin meslekteki dezavantajları da kadın hemşireler açısından dezavantaja dönüşebilir. Bir kadın mesleğinde çalıştıkları için sorgulandıklarını düşünen erkek hemşirelerin erkekliklerini yeniden üretme, pekiştirme ve savunma süreçleri, toplumsal cinsiyet eşitsizliklerinin mesleğe daha çok yansımasına, 
kadın hemşireler üzerinde kurulan eril tahakkümün derinleşmesine neden olabilir.

Yoğun olarak kadınların çalıştığı hemşirelik mesleğinin pratiklerinde toplumsal cinsiyet eşitsizliklerinin meşrulaştırılmasına ve cam tavanın içselleştirilmesine neden olan bakış açısı sorgulanmalıdır. Hem hemşirelik mesleği içinde ataerkil bir işbölümü yaratılmaması için, hem de hemşirelerin doktorlarla olan etkileşimlerinde güçlenebilmeleri için toplumsal cinsiyet eşitliği perspektifi güçlendirilmeli, bakım işleri ile kadınlık arasındaki ilişki çözülmelidir. Bu çözülme, aklı ve duyguları birbirine zıt konumlandıran ve erkeklik ve kadınlıkla ilişkilendiren bakış açısının terkedilmesine bağlıdır. Kısa vadede erkek hemşirelere avantaj sağlıyor gibi görünen ataerkil ideolojinin ve hegemonik erkekliğin yarattı̆̆ 1 çifte bilinçlilik erkek hemşirelerin hastalarla, doktorlarla ve kadın hemşirelerle daha nitelikli ilişkiler kurmasını engelleyecek gibi görünmektedir. Dolayısıyla sadece kadın hemşirelerin değil, erkek hemşirelerin de mesleki konumlarının iyileştirilmesi, ataerkil ideolojinin hemşirelik mesleği üzerindeki etkisinin azaltılmasına bağlıdır.

\section{Kaynakça}

Acar-Savran, Gülnur (2004), Beden Emek Tarih: Diyalektik Bir Feminizm İçin (İstanbul: Kanat Yayınları).

Andrews, Mary E., Norma J. Stewart, Debra G. Morgan ve Carl D'Arcy (2012), "More Alike Than Different: A Comparison of Male and Female RNs in Rural and Remote Canada", Journal of Nursing Management, 20 (4): 561-570.

Atay, Tayfun (2012), Çin İşi Japon İşi: Cinsiyet ve Cinsellik Üzerine Antropolojik Değiniler (İstanbul: İletişim Yayınları).

Baby, Maria, Glue, Paul ve Dave Carlyle (2014), “'Violence is Not Part of Our Job': A Thematic Analysis of Psychiatric Mental Health Nurses' Experiences of Patient Assaults From a New Zealand Perspective", Issues in Mental Health Nursing, 35 (9): 647-655.

Battice, Juliet (2010), "Editorial: The Changing Face of Nursing in a Developing Country", Journal of Clinical Nursing, 19 (13-14): 1765-1766.

Bernard Hodes Group (2005), Men In Nursing Study, Hodes Research. http://aamn.org/docs/meninnursing 2005survey.pdf (22.08.2015).

Bourdieu, Pierre (2014), Eril Tahakküm (İstanbul: Bağlam Yayınları) (Çev. Bediz Yılmaz). 
Brown, Brian (2009), "Men in Nursing: Re-evaluating Masculinities, Re-evaluating Gender", Contemporary Nurse, 33 (2): 120-129.

Brown, Claire ve Liz Jones (2004), "The Gender Structure of the Nursing Hierarchy: The Role of Human Capital", Gender, Work and Organization, 11 (1): 1-25.

Bush, Patricia J. (1976), "The Male Nurse: A Challenge to Traditional Role Identities", Nursing Forum, 15 (4): 390-405.

Chiarella, Mary ve Amanda Adrian (2014), "Boundary Violations, Gender and The Nature of Nursing Work", Nursing Ethics, 21 (3): 267-277.

Cockburn, C. (1983), Brothers. Male Dominance and Technological Change (London: Pluto Press).

Connell, R. W. (1998), Toplumsal Cinsiyet ve Íktidar (İstanbul: Ayrıntı Yayınları) (Çev: Cem Soydemir).

Dikmen Özarslan, Aylin (2015), "Hegemonik Erkeklik Bağlamında Erkek Hemşìreler", Alternatif Politika, 7 (1): 118-142

Ecevit, Yıldız (1998), “Türkiye'de Ücretli Kadın Emeğinin Toplumsal Cinsiyet Temelinde Analizi”, Hacımirzaoğlu, Ayşe Berktay (Der.), 75. Yılda Kadınlar ve Erkekler (İstanbul: Türkiye Ekonomik ve Toplumsal Tarih Vakfı ve Yapı Kredi Yayınları): 267-284.

Ehrenreich, Barbara ve Deidre English (1992), Cadılar, Büyücüler ve Hemşireler (İstanbul: Kavram Yayınları) (Çev. Ergun Uğur)

England, Kim V.L. (1993), "Suburban Pink Collar Ghettos: The Spatial Entrapment of Women?", Annals of the Association of American Geographers, 83 (2): 225-242.

Evans, Joan (1997), "Men in Nursing: Issues of Gender Segregation and Hidden Advantage", Journal of Advanced Nursing, 26 (2): 226-231.

Evans, Joan (2002), "Cautious Caregivers: Gender Stereotypes and the Sexualisation of Men Nurses' Touch", Journal of Advanced Nursing, 40 (4): 441-448.

Evans, Joan (2004), "Men Nurses: A Historical and Feminist Perspective", Journal of Advanced Nursing, 47 (3): 321-328.

Federici, Silvia (2012), Caliban ve Cadı: Kadınlar, Beden ve Illksel Birikim (İstanbul: Otonom Yayıncılık) (Çev. Öznur Karakaş)

Fisher, Murray J. (2009), "Being a Chameleon': Labour Processes of Male Nurses Performing Bodywork", Journal of Advanced Nursing, 65 (12): 2668-2677.

Fox Keller, Evelyn (1985), Reflections on Gender and Science (New Haven: Yale University Press).

Gamarnikow, Eva (1978), "Sexual Division of Labour: The Case of Nursing" Kuhn, Anette ve Annmarie Wolpe (Der.), Feminism and Materialism (London: Routledge and Kegan Paul): 96-123.

Garfinkel, Harold (1967), Studies in Ethnomethodology (Englewood Cliffs, NJ: Prentice-Hall).

Gönç, Temmuz (2016), “Kadın Yoğun Meslekleri Erilleştirmeye Yönelik Stratejiler: Türkiye'de Erkek Hemşireler Örneği", Sosyoloji Araştırmaları Dergisi, 19 (1).

Hader, Richard (2005), "Salary Survey 2005”, Nursing Management, 36 (7): 18-27.

Hakim, Catherine (1979), Occupational Segregation: A Comparative Study of the Degree and Pattern of the Differentiation Between Men and Women's Work in Britain, the United States and Other Countries (London: Department of Employment Research Paper No. 9).

Harding, Thomas (2007), "The Construction of Men who are Nurses as Gay", Journal of Advanced Nursing, 60 (6): 636-644. 
Hart, Karen A. (2005), "Study: Who are the Men in Nursing?", National Student Nurses Association Imprint, (November-December): 32-34.

Heikes, Joel E. (1991), "When Men are the Minority: The Case of Men in Nursing", The Sociological Quarterly, 32 (3): 389-401.

Herdman, Elizabeth ve Aysel Badir (2008), "Gender Equality or Patriarchal Dividend: Structural Change in Turkish Nursing", Nursing and Health Sciences, 10 (2): 159-163.

Hochschild, Arlie ve Anne Machung (2012), The Second Shift (New York: Penguin Books).

Howe, Louise Kapp (1978), Pink Collar Workers: Inside the World of Women's Work (New York: Avon Books).

Inoue, Madoka, Chapman, Rose ve Dianne Wynaden (2006), "Male Nurses' Experiences of Providing Intimate Care for Women Clients", Journal of Advanced Nursing, 55 (5): 559567.

Kellett, Peter, Gregory, David M. ve Joan A. Evans (2014), "Patriarchal Paradox: Gender Performance and Men's Nursing Careers", Gender in Management: An International Journal, 29 (2): 77-90.

Keogh, Brian ve Madeline Gleeson (2006), "Caring for Female Patients: The Experience of Male Nurses", British Journal of Nursing, 15 (21): 1172-1175.

LaRocco, Susan A. (2007), "A Grounded Theory Study of Socializing Men into Nursing", The Journal of Men's Studies, 15 (2): 120-129.

Liminana-Gras, Rosa M., M. Pilar Sanchez-Lopez, Ana I. Saavedra-San Roman, ve F. Javier Corbalan-Berna (2013), "Health and Gender in Female-Dominated Occupations: The Case of Male Nurses", The Journal of Men's Studies, 21 (2): 135-148.

Lindsay, Sally (2007), "Gendering Work: The Masculinization of Nurse Anesthesia”, The Canadian Journal of Sociology, 32 (4): 429-448.

Lloyd, Genevieve (1996), Erkek Akıl (İstanbul: Ayrıntı Yayınları) (Çev. Muttalip Özcan).

Lodge, Nicholas, Jane Mallett, Peter Blake ve lan Fryatt (1997), "A Study to Ascertain Gynecological Patients' Perceived Levels of Endorsement with Physical and Psychological Care Given by Female and Male Nurses”, Journal of Advanced Nursing, 25 (5): 893-907.

Lou, Jiunn-Horng, Hsing-Y Yu, Hsiu-Yueh Hsu ve Hung-Da Dai (2007), "A Study of Role Stress, Organizational Commitment and Intention of Turnover for Male Nurses in Southern Taiwan", Journal of Nursing Research, 15 (1): 43-53.

Loughrey, Mark (2008), “Just How Male are Male Nurses?” Journal of Clinical Nursing, 17 (10) 1327-1334.

MacDougall, Graham (1997), “Caring: A Masculine Perspective”, Journal of Advanced Nursing, 25 (4): 809-813.

Marsland, Louise, Sarah Robinson ve Trevor Murrells (2003), "Pursuing a career in nursing: Differences Between Men and Women Qualifying as Registered General Nurses", Journal of Nursing Management, 4 (4): 231-241.

Matthews, Shaun. (2001), "Registered Male: A Discussion on Men in the Nursing Profession", Contemporary Nurse, 11 (2-3): 231-235.

Mclean, Heather M. ve Rudolf Kalin (1994), "Congruence Between Self-Image and Occupational Stereotypes in Students Entering Gender-Dominated Occupations and Workplaces", Canadian Journal of Behavioural Science, 26 (1): 142-162.

Meadus, Robert J. (2000), "Men in Nursing: Barriers to Recruitment”, Nursing Forum, 35 (3): 5-14 
Meadus, Robert J. ve J. Creina Twomey (2007), "Men in Nursing: Making the Right Choice", Canadian Nurse, 103 (2): 13-16.

Muench, Ulrike, Jody Sindelar, Susan H. Busch ve Peter I. Buerhaus (2015), "Salary Differences Between Male and Female Registered Nurses in the United States", The Journal of the American Medical Association, 313 (12): 1265-1267.

O'Lynn, Chad ve Russell Tranberger (2006), Men in Nursing: History, Challenges and Opportunities (New York: Springer)

Orbe, Mark P. (1998), "An 'Outsider Within' Perspective to Organizational Communication”, Management Communication Quarterly, 12 (2): 230-279.

Philips, Anne ve Barbara Taylor (1980), "Sex and Skill: Notes Towards a Feminist Economics", Feminist Review, 6: 79-88.

Poole, Marilyn ve Dallas Isaacs (1997), “Caring: A Gendered Concept”, Women's Studies International Forum, 20 (4): 529-536.

Porter, Sam (1992), "Women in a Women's Job: The Gendered Experience of Nurses", Sociology of Health and IIIness, 14 (4): 510-527.

Roberts, Joan I. ve Thetis M. Group (1995), Feminism and Nursing: An Historical Perspective on Power, Status and Political Activism in The Nursing Profession (Westport, CT: Praeger).

Sancar, Serpil (2013), Erkeklik: Imkansız Iktidar: Ailede, Piyasada ve Sokakta Erkekler (İstanbul: Metis Yayıncılık).

Simpson, Ruth (2005), "Men in Non-Traditional Occupations: Career Entry, Career Orientation and Experience of Role Strain", Gender Work and Organization, 12 (4): 363-380.

Sinclair, M.Thea (1991), "Women, Work and Skill: Economic Theories and Feminist Perspectives", Sinclair, M. Thea ve Nanneke Redclift (Der.), Working Women, International Perspectives on Labour and Gender Ideology (London: Routledge): 1-24.

Smith, Joshua S. (2006), "Exploring the Challenges for Nontraditional Male Students Transitioning into a Nursing Program", Journal of Nursing Education, 45 (7): 263-269.

Street, Anette F. (1992), Inside Nursing: A Critical Ethnography of Clinical Nursing Practice (New York: SUNY Press).

Şimşek-Rathke, Leyla (2011), Dünden Kalanlar: Türkiye'de Hemşirelik ve GATA TSK Sağlık Meslek Lisesi Örneği (İstanbul: İletişim Yayınları).

Tarihçi-Delice, S. (2006), Hemşirelik Mesleği ve Toplumsal Cinsiyet Rollerinin Hemşirelik Mesleğine Etkilerinin Betimlenmesi, Yayımlanmamış Yüksek Lisans Tezi (Ankara: Ankara Üniversitesi Sosyal Bilimler Enstitüsü Hemşirelik Anabilim Dalı).

T.C. Sağlık Bakanlığı (2014), Sağlık İstatistikleri Yıllığı (Ankara: Sağlık Araştırmaları Gene Müdürlüğü).

Taylor, Catherine J. (2010), "Occupational Sex Composition and the Gendered Availability of workplace Support”, Gender \& Society, 24 (2): 189-212.

Tracey, Catherine ve Honor Nicholl (2007), "The Multifaceted Influence of Gender in Career Progress in Nursing", Journal of Nursing Management, 15 (7): 677-682.

Turner, Bryan S. (2011), Tıbbi Güç ve Toplumsal Bilgi (İstanbul: Sentez Yayınları) (Çev. Ümit Tatlıcan).

Urhan, Betül ve Nilay Etiler (2011), "Sağlık Sektöründe Kadın Emeğinin Toplumsal Cinsiyet Açısından Analizi”, Çalışma ve Toplum, 2 (29): 191-215.

Walby, Sylvia (1990), Theorizing Patriarchy (Oxford: Blackwell). 
Waters, Mike Postic, Durocher, Sharla, Donker, Heather ve Ben Brenner (1999), "Janforum", Journal of Advanced Nursing, 29 (2): 523.

Williams, Christine L. (1992), "The Glass Escalator: Hidden Advantages for Men in the 'Female' Professions", Social Problems, 39 (3): 253-267.

Williams, Christine L. (Der.) (1993), Doing "Women's Work": Men in Nontraditional Occupations (Thousand Oaks: Sage).

Wingfield, Adia Harvey (2009), "Racializing the Glass Escalator: Reconsidering Men's Experiences with Women's Work", Gender and Society, 23 (5): 5-26.

Zamanzadeh, Vahid, Arman Azadi, Leila Valizadeh, Brian Keogh, Morteza Monadive ve Reza Negarandeh (2013), "Choosing and Remaining in Nursing: Iranian Male Nurses' Perspectives", Contemporary Nurse, 45 (2): 220-227. 